\title{
THE ISRAEL LOBBY AND U.S. FOREIGN POLICY
}

\author{
John J. Mearsheimer \\ Department of Political Science \\ University of Chicago
}

\author{
Stephen M. Walt \\ John F. Kennedy School of Government \\ Harvard University
}

March 2006

RWP06-011

The two authors of this Working Paper are solely responsible for the views expressed in it. As academic institutions, Harvard University and the University of Chicago do not take positions on the scholarship of individual faculty, and this article should not be interpreted or portrayed as reflecting the official position of either institution.

An edited and reworked version of this paper was published in the London Review of Books Vol. 28, No. 6 (March 23, 2006), and is available online at www.lrb.co.uk 


\section{THE ISRAEL LOBBY AND U.S. FOREIGN POLICY}

U.S. foreign policy shapes events in every corner of the globe. Nowhere is this truer than in the Middle East, a region of recurring instability and enormous strategic importance. Most recently, the Bush Administration's attempt to transform the region into a community of democracies has helped produce a resilient insurgency in Iraq, a sharp rise in world oil prices, and terrorist bombings in Madrid, London, and Amman. With so much at stake for so many, all countries need to understand the forces that drive U.S. Middle East policy.

The U.S. national interest should be the primary object of American foreign policy. For the past several decades, however, and especially since the Six Day War in 1967, the centerpiece of U.S. Middle East policy has been its relationship with Israel. The combination of unwavering U.S. support for Israel and the related effort to spread democracy throughout the region has inflamed Arab and Islamic opinion and jeopardized U.S. security.

This situation has no equal in American political history. Why has the United States been willing to set aside its own security in order to advance the interests of another state? One might assume that the bond between the two countries is based on shared strategic interests or compelling moral imperatives. As we show below, however, neither of those explanations can account for the remarkable level of material and diplomatic support that the United States provides to Israel.

Instead, the overall thrust of U.S. policy in the region is due almost entirely to U.S. domestic politics, and especially to the activities of the "Israel Lobby." Other special interest groups have managed to skew U.S. foreign policy in directions they favored, but no lobby has managed to divert U.S. foreign policy as far from what the American national interest would otherwise suggest, while simultaneously convincing Americans that U.S. and Israeli interests are essentially identical. ${ }^{1}$

In the pages that follow, we describe how the Lobby has accomplished this feat, and how its activities have shaped America's actions in this critical region. Given the strategic importance of the Middle East and its potential impact on 
others, both Americans and non-Americans need to understand and address the Lobby's influence on U.S. policy.

Some readers will find this analysis disturbing, but the facts recounted here are not in serious dispute among scholars. Indeed, our account relies heavily on the work of Israeli scholars and journalists, who deserve great credit for shedding light on these issues. We also rely on evidence provided by respected Israeli and international human rights organizations. Similarly, our claims about the Lobby's impact rely on testimony from the Lobby's own members, as well as testimony from politicians who have worked with them. Readers may reject our conclusions, of course, but the evidence on which they rest is not controversial.

\section{THE GREAT BENEFACTOR}

Since the October War in 1973, Washington has provided Israel with a level of support dwarfing the amounts provided to any other state. It has been the largest annual recipient of direct U.S. economic and military assistance since 1976 and the largest total recipient since World War II. Total direct U.S. aid to Israel amounts to well over $\$ 140$ billion in 2003 dollars. ${ }^{2}$ Israel receives about $\$ 3$ billion in direct foreign assistance each year, which is roughly one-fifth of America's foreign aid budget. In per capita terms, the United States gives each Israeli a direct subsidy worth about $\$ 500$ per year. ${ }^{3}$ This largesse is especially striking when one realizes that Israel is now a wealthy industrial state with a per capita income roughly equal to South Korea or Spain. ${ }^{4}$

Israel also gets other special deals from Washington. ${ }^{5}$ Other aid recipients get their money in quarterly installments, but Israel receives its entire appropriation at the beginning of each fiscal year and thus earns extra interest. Most recipients of American military assistance are required to spend all of it in the United States, but Israel can use roughly twenty-five percent of its aid allotment to subsidize its own defense industry. Israel is the only recipient that does not have to account for how the aid is spent, an exemption that makes it virtually impossible to prevent the money from being used for purposes the United States opposes, like building settlements in the West Bank.

Moreover, the United States has provided Israel with nearly $\$ 3$ billion to develop weapons systems like the Lavi aircraft that the Pentagon did not want or need, while giving Israel access to top-drawer U.S. weaponry like Blackhawk helicopters and F-16 jets. Finally, the United States gives Israel access to 
intelligence that it denies its NATO allies and has turned a blind eye towards Israel's acquisition of nuclear weapons. ${ }^{6}$

In addition, Washington provides Israel with consistent diplomatic support. Since 1982, the United States has vetoed 32 United Nations Security Council resolutions that were critical of Israel, a number greater than the combined total of vetoes cast by all the other Security Council members. ${ }^{7}$ It also blocks Arab states' efforts to put Israel's nuclear arsenal on the International Atomic Energy Agency's agenda. ${ }^{8}$

The United States also comes to Israel's rescue in wartime and takes its side when negotiating peace. The Nixon Administration re-supplied Israel during the October War and protected Israel from the threat of Soviet intervention. Washington was deeply involved in the negotiations that ended that war as well as the lengthy "step-by-step" process that followed, just as it played a key role in the negotiations that preceded and followed the 1993 Oslo Accords. ${ }^{9}$ There were occasional frictions between U.S. and Israeli officials in both cases, but the United States coordinated its positions closely with Israel and consistently backed the Israeli approach to the negotiations. Indeed, one American participant at Camp David (2000) later said, "far too often, we functioned ... as Israel's lawyer."10

As discussed below, Washington has given Israel wide latitude in dealing with the occupied territories (the West Bank and Gaza Strip), even when its actions were at odds with stated U.S. policy. Moreover, the Bush Administration's ambitious strategy to transform the Middle East-beginning with the invasion of Iraq-is at least partly intended to improve Israel's strategic situation. Apart from wartime alliances, it is hard to think of another instance where one country has provided another with a similar level of material and diplomatic support for such an extended period. America's support for Israel is, in short, unique.

This extraordinary generosity might be understandable if Israel were a vital strategic asset or if there were a compelling moral case for sustained U.S. backing. But neither rationale is convincing.

\section{A STRATEGIC LIABILITY}

According to the American-Israel Public Affairs Committee's (AIPAC) website, "the United States and Israel have formed a unique partnership to meet the growing strategic threats in the Middle East.... This cooperative effort provides significant benefits for both the United States and Israel."11 This claim is an 
article of faith among Israel's supporters and is routinely invoked by Israeli politicians and pro-Israel Americans.

Israel may have been a strategic asset during the Cold War. ${ }^{12}$ By serving as America's proxy after the Six Day War (1967), Israel helped contain Soviet expansion in the region and inflicted humiliating defeats on Soviet clients like Egypt and Syria. Israel occasionally helped protect other U.S. allies (like Jordan's King Hussein) and its military prowess forced Moscow to spend more backing its losing clients. Israel also gave the United States useful intelligence about Soviet capabilities.

Israel's strategic value during this period should not be overstated, however. ${ }^{13}$ Backing Israel was not cheap, and it complicated America's relations with the Arab world. For example, the U.S. decision to give Israel $\$ 2.2$ billion in emergency military aid during the October War triggered an OPEC oil embargo that inflicted considerable damage on Western economies. Moreover, Israel's military could not protect U.S. interests in the region. For example, the United States could not rely on Israel when the Iranian Revolution in 1979 raised concerns about the security of Persian Gulf oil supplies, and had to create its own "Rapid Deployment Force" instead.

Even if Israel was a strategic asset during the Cold War, the first Gulf War (199091) revealed that Israel was becoming a strategic burden. The United States could not use Israeli bases during the war without rupturing the anti-Iraq coalition, and it had to divert resources (e.g., Patriot missile batteries) to keep Tel Aviv from doing anything that might fracture the alliance against Saddam. History repeated itself in 2003: although Israel was eager for the United States to attack Saddam, President Bush could not ask it to help without triggering Arab opposition. So Israel stayed on the sidelines again. ${ }^{14}$

Beginning in the 1990s, and especially after 9/11, U.S. support for Israel has been justified by the claim that both states are threatened by terrorist groups originating in the Arab or Muslim world, and by a set of "rogue states" that back these groups and seek WMD. This rationale implies that Washington should give Israel a free hand in dealing with the Palestinians and not press Israel to make concessions until all Palestinian terrorists are imprisoned or dead. It also implies that the United States should go after countries like the Islamic Republic of Iran, Saddam Hussein's Iraq, and Bashar al-Assad's Syria. Israel is thus seen as a crucial ally in the war on terror, because its enemies are America's enemies. 
This new rationale seems persuasive, but Israel is in fact a liability in the war on terror and the broader effort to deal with rogue states.

To begin with, "terrorism" is a tactic employed by a wide array of political groups; it is not a single unified adversary. The terrorist organizations that threaten Israel (e.g., Hamas or Hezbollah) do not threaten the United States, except when it intervenes against them (as in Lebanon in 1982). Moreover, Palestinian terrorism is not random violence directed against Israel or "the West"; it is largely a response to Israel's prolonged campaign to colonize the West Bank and Gaza Strip.

More importantly, saying that Israel and the United States are united by a shared terrorist threat has the causal relationship backwards: rather, the United States has a terrorism problem in good part because it is so closely allied with Israel, not the other way around. U.S. support for Israel is not the only source of antiAmerican terrorism, but it is an important one, and it makes winning the war on terror more difficult. ${ }^{15}$ There is no question, for example, that many al Qaeda leaders, including bin Laden, are motivated by Israel's presence in Jerusalem and the plight of the Palestinians. According to the U.S. 9/11 Commission, bin Laden explicitly sought to punish the United States for its policies in the Middle East, including its support for Israel, and he even tried to time the attacks to highlight this issue. ${ }^{16}$

Equally important, unconditional U.S. support for Israel makes it easier for extremists like bin Laden to rally popular support and to attract recruits. Public opinion polls confirm that Arab populations are deeply hostile to American support for Israel, and the U.S. State Department's Advisory Group on Public Diplomacy for the Arab and Muslim world found that "citizens in these countries are genuinely distressed at the plight of the Palestinians and at the role they perceive the United States to be playing." 17

As for so-called rogue states in the Middle East, they are not a dire threat to vital U.S. interests, apart from the U.S. commitment to Israel itself. Although the United States does have a number of disagreements with these regimes, Washington would not be nearly as worried about Iran, Ba'thist Iraq, or Syria were it not so closely tied to Israel. Even if these states acquire nuclear weapons - which is obviously not desirable - it would not be a strategic disaster for the United States. Neither America nor Israel could be blackmailed by a nuclear-armed rogue, because the blackmailer could not carry out the threat without receiving overwhelming retaliation. The danger of a "nuclear handoff" 
to terrorists is equally remote, because a rogue state could not be sure the transfer would be undetected or that it would not be blamed and punished afterwards.

Furthermore, the U.S. relationship with Israel actually makes it harder to deal with these states. Israel's nuclear arsenal is one reason why some of its neighbors want nuclear weapons, and threatening these states with regime change merely increases that desire. Yet Israel is not much of an asset when the United States contemplates using force against these regimes, because it cannot participate in the fight.

In short, treating Israel as America's most important ally in the campaign against terrorism and assorted Middle East dictatorships both exaggerates Israel's ability to help on these issues and ignores the ways that Israel's policies make U.S. efforts more difficult.

Unquestioned support for Israel also weakens the U.S. position outside the Middle East. Foreign elites consistently view the United States as too supportive of Israel, and think its tolerance of Israeli repression in the occupied territories is morally obtuse and a handicap in the war on terrorism. ${ }^{18}$ In April 2004, for example, 52 former British diplomats sent Prime Minister Tony Blair a letter saying that the Israel-Palestine conflict had "poisoned relations between the West and the Arab and Islamic worlds," and warning that the policies of Bush and Prime Minister Ariel Sharon were "one-sided and illegal."19

A final reason to question Israel's strategic value is that it does not act like a loyal ally. Israeli officials frequently ignore U.S. requests and renege on promises made to top U.S. leaders (including past pledges to halt settlement construction and to refrain from "targeted assassinations" of Palestinian leaders). ${ }^{20}$ Moreover, Israel has provided sensitive U.S. military technology to potential U.S. rivals like China, in what the U.S. State Department Inspector-General called "a systematic and growing pattern of unauthorized transfers." ${ }^{21}$ According to the U.S. General Accounting Office, Israel also "conducts the most aggressive espionage operations against the U.S. of any ally." 22 In addition to the case of Jonathan Pollard, who gave Israel large quantities of classified material in the early 1980s (which Israel reportedly passed onto the Soviet Union to gain more exit visas for Soviet Jews), a new controversy erupted in 2004 when it was revealed that a key Pentagon official (Larry Franklin) had passed classified information to an Israeli diplomat, allegedly aided by two AIPAC officials. ${ }^{23}$ Israel is hardly the only 
country that spies on the United States, but its willingness to spy on its principal patron casts further doubt on its strategic value. 


\section{A DWINDLING MORAL CASE}

Apart from its alleged strategic value, Israel's backers also argue that it deserves unqualified U.S. support because 1) it is weak and surrounded by enemies, 2) it is a democracy, which is a morally preferable form of government; 3 ) the Jewish people have suffered from past crimes and therefore deserve special treatment, and 4) Israel's conduct has been morally superior to its adversaries' behavior.

On close inspection, however, each of these arguments is unpersuasive. There is a strong moral case for supporting Israel's existence, but that is not in jeopardy. Viewed objectively, Israel's past and present conduct offers no moral basis for privileging it over the Palestinians.

\section{Backing the Underdog?}

Israel is often portrayed as weak and besieged, a Jewish David surrounded by a hostile Arab Goliath. This image has been carefully nurtured by Israeli leaders and sympathetic writers, but the opposite image is closer to the truth. Contrary to popular belief, the Zionists had larger, better-equipped, and better-led forces during the 1947-49 War of Independence and the Israel Defense Forces (IDF) won quick and easy victories against Egypt in 1956 and against Egypt, Jordan, and Syria in 1967-before large-scale U.S. aid began flowing to Israel. ${ }^{24}$ These victories offer eloquent evidence of Israeli patriotism, organizational ability, and military prowess, but they also reveal that Israel was far from helpless even in its earliest years.

Today, Israel is the strongest military power in the Middle East. Its conventional forces are far superior to its neighbors and it is the only state in the region with nuclear weapons. Egypt and Jordan signed peace treaties with Israel and Saudi Arabia has offered to do so as well. Syria has lost its Soviet patron, Iraq has been decimated by three disastrous wars, and Iran is hundreds of miles away. The Palestinians barely have effective police, let alone a military that could threaten Israel. According to a 2005 assessment by Tel Aviv University's prestigious Jaffee Center for Strategic Studies, "the strategic balance decidedly favors Israel, which has continued to widen the qualitative gap between its own military capability and deterrence powers and those of its neighbors." ${ }^{25}$ If backing the underdog were a compelling rationale, the United States would be supporting Israel's opponents. 


\section{Aiding a Fellow Democracy?}

American backing is often justified by the claim that Israel is a fellow-democracy surrounded by hostile dictatorships. This rationale sounds convincing, but it cannot account for the current level of U.S. support. After all, there are many democracies around the world, but none receives the lavish support that Israel does. The United States has overthrown democratic governments in the past and supported dictators when this was thought to advance U.S. interests, and it has good relations with a number of dictatorships today. Thus, being democratic neither justifies nor explains America's support for Israel.

The "shared democracy" rationale is also weakened by aspects of Israeli democracy that are at odds with core American values. The United States is a liberal democracy where people of any race, religion, or ethnicity are supposed to enjoy equal rights. By contrast, Israel was explicitly founded as a Jewish state and citizenship is based on the principle of blood kinship. ${ }^{26}$ Given this conception of citizenship, it is not surprising that Israel's 1.3 million Arabs are treated as second-class citizens, or that a recent Israeli government commission found that Israel behaves in a "neglectful and discriminatory" manner towards them. ${ }^{27}$

Similarly, Israel does not permit Palestinians who marry Israeli citizens to become citizens themselves, and does not give these spouses the right to live in Israel. The Israeli human rights organization B'tselem called this restriction "a racist law that determines who can live here according to racist criteria." ${ }^{28}$ Such laws may be understandable given Israel's founding principles, but they are not consistent with America's image of democracy.

Israel's democratic status is also undermined by its refusal to grant the Palestinians a viable state of their own. Israel controls the lives of about 3.8 million Palestinians in Gaza and the West Bank, while colonizing lands on which the Palestinians have long dwelt. Israel is formally democratic, but the millions of Palestinians that it controls are denied full political rights and the "shared democracy" rationale is correspondingly weakened.

\section{Compensation for Past Crimes}

A third moral justification is the history of Jewish suffering in the Christian West, especially the tragic episode of the Holocaust. Because Jews were persecuted for 
centuries and can only be safe in a Jewish homeland, many believe that Israel deserves special treatment from the United States.

There is no question that Jews suffered greatly from the despicable legacy of antiSemitism, and that Israel's creation was an appropriate response to a long record of crimes. This history, as noted, provides a strong moral case for supporting Israel's existence. But the creation of Israel involved additional crimes against a largely innocent third party: the Palestinians.

The history of these events is well-understood. When political Zionism began in earnest in the late $19^{\text {th }}$ century, there were only about 15,000 Jews in Palestine. ${ }^{29}$ In 1893, for example, the Arabs comprised roughly 95 percent of the population, and though under Ottoman control, they had been in continuous possession of this territory for 1300 years. ${ }^{30}$ Even when Israel was founded, Jews were only about 35 percent of Palestine's population and owned 7 percent of the land. ${ }^{31}$

The mainstream Zionist leadership was not interested in establishing a binational state or accepting a permanent partition of Palestine. The Zionist leadership was sometimes willing to accept partition as a first step, but this was a tactical maneuver and not their real objective. As David Ben-Gurion put it in the late 1930s, "After the formation of a large army in the wake of the establishment of the state, we shall abolish partition and expand to the whole of Palestine." ${ }^{32}$

To achieve this goal, the Zionists had to expel large numbers of Arabs from the territory that would eventually become Israel. There was simply no other way to accomplish their objective. Ben-Gurion saw the problem clearly, writing in 1941 that "it is impossible to imagine general evacuation [of the Arab population] without compulsion, and brutal compulsion." 33 Or as Israeli historian Benny Morris puts it, "the idea of transfer is as old as modern Zionism and has accompanied its evolution and praxis during the past century." 34

This opportunity came in 1947-48, when Jewish forces drove up to 700,000 Palestinians into exile. ${ }^{35}$ Israeli officials have long claimed that the Arabs fled because their leaders told them to, but careful scholarship (much of it by Israeli historians like Morris) have demolished this myth. In fact, most Arab leaders urged the Palestinian population to stay home, but fear of violent death at the hands of Zionist forces led most of them to flee. ${ }^{36}$ After the war, Israel barred the return of the Palestinian exiles. 
The fact that the creation of Israel entailed a moral crime against the Palestinian people was well understood by Israel's leaders. As Ben-Gurion told Nahum Goldmann, president of the World Jewish Congress, "If I were an Arab leader I would never make terms with Israel. That is natural: we have taken their country.... We come from Israel, but two thousand years ago, and what is that to them? There has been anti-Semitism, the Nazis, Hitler, Auschwitz, but was that their fault? They only see one thing: we have come here and stolen their country. Why should they accept that?"37

Since then, Israeli leaders have repeatedly sought to deny the Palestinians' national ambitions. ${ }^{38}$ Prime Minister Golda Meir famously remarked that "there was no such thing as a Palestinian," and even Prime Minister Yitzhak Rabin, who signed the 1993 Oslo Accords, nonetheless opposed creating a full-fledged Palestinian state. ${ }^{39}$ Pressure from extremist violence and the growing Palestinian population has forced subsequent Israeli leaders to disengage from some of the occupied territories and to explore territorial compromise, but no Israeli government has been willing to offer the Palestinians a viable state of their own. Even Prime Minister Ehud Barak's purportedly generous offer at Camp David in July 2000 would only have given the Palestinians a disarmed and dismembered set of "Bantustans" under de facto Israeli control. ${ }^{40}$

Europe's crimes against the Jews provide a clear moral justification for Israel's right to exist. But Israel's survival is not in doubt-even if some Islamic extremists make outrageous and unrealistic references to "wiping it off the map" - and the tragic history of the Jewish people does not obligate the United States to help Israel no matter what it does today.

\section{“Virtuous Israelis" versus “Evil Arabs"}

The final moral argument portrays Israel as a country that has sought peace at every turn and showed great restraint even when provoked. The Arabs, by contrast, are said to have acted with great wickedness. This narrative-which is endlessly repeated by Israeli leaders and American apologists such as Alan Dershowitz-is yet another myth. ${ }^{41}$ In terms of actual behavior, Israel's conduct is not morally distinguishable from the actions of its opponents.

Israeli scholarship shows that the early Zionists were far from benevolent towards the Palestinian Arabs. ${ }^{42}$ The Arab inhabitants did resist the Zionists' encroachments, which is hardly surprising given that the Zionists were trying to create their own state on Arab lands. The Zionists responded vigorously, and 
neither side owns the moral high ground during this period. This same scholarship also reveals that the creation of Israel in 1947-48 involved explicit acts of ethnic cleansing, including executions, massacres, and rapes by Jews. ${ }^{43}$

Furthermore, Israel's subsequent conduct towards its Arab adversaries and its Palestinian subjects has often been brutal, belying any claim to morally superior conduct. Between 1949 and 1956, for example, Israeli security forces killed between 2,700 and 5000 Arab infiltrators, the overwhelming majority of them unarmed. ${ }^{44}$ The IDF conducted numerous cross-border raids against its neighbors in the early 1950s, and though these actions were portrayed as defensive responses, they were actually part of a broader effort to expand Israel's borders. Israel's expansionist ambitions also led it to join Britain and France in attacking Egypt in 1956, and Israel withdrew from the lands it had conquered only in the face of intense U.S. pressure. ${ }^{45}$

The IDF also murdered hundreds of Egyptian prisoners-of-war in both the 1956 and 1967 wars. $^{46}$ In 1967, it expelled between 100,000 and 260,000 Palestinians from the newly-conquered West Bank, and drove 80,000 Syrians from the Golan Heights. ${ }^{47}$ It was also complicit in the massacre of 700 innocent Palestinians at the Sabra and Shatila refugee camps following its invasion of Lebanon in 1982, and an Israeli investigatory commission found then-Defence Minister Sharon "personally responsible" for these atrocities. ${ }^{48}$

Israeli personnel have tortured numerous Palestinian prisoners, systematically humiliated and inconvenienced Palestinian civilians, and used force indiscriminately against them on numerous occasions. During the First Intifida (1987-1991), for example, the IDF distributed truncheons to its troops and encouraged them to break the bones of Palestinian protestors. The Swedish "Save the Children" organization estimated that "23,600 to 29,900 children required medical treatment for their beating injuries in the first two years of the intifida," with nearly one-third sustaining broken bones. Nearly one-third of the beaten children were aged ten and under." 49

Israel's response to the Second Intifida (2000-2005) has been even more violent, leading $H a^{\prime}$ aret $z$ to declare that "the IDF ... is turning into a killing machine whose efficiency is awe-inspiring, yet shocking." ${ }^{50}$ The IDF fired one million bullets in the first days of the uprising, which is far from a measured response. ${ }^{51}$ Since then, Israel has killed 3.4 Palestinians for every Israeli lost, the majority of whom have been innocent bystanders; the ratio of Palestinian to Israeli children killed is even higher (5.7 to 1). ${ }^{52}$ Israeli forces have also killed several foreign 
peace activists, including a 23 year-old American woman crushed by an Israeli bulldozer in March 2003.53

These facts about Israel's conduct have been amply documented by numerous human rights organizations - including prominent Israeli groups - and are not disputed by fair-minded observers. And that is why four former officials of Shin Bet (the Israeli domestic security organization) condemned Israel's conduct during the Second Intifada in November 2003. One of them declared "we are behaving disgracefully," and another termed Israel's conduct "patently immoral." ${ }^{54}$

But isn't Israel entitled to do whatever it takes to protect its citizens? Doesn't the unique evil of terrorism justify continued U.S. support, even if Israel often responds harshly?

In fact, this argument is not a compelling moral justification either. Palestinians have used terrorism against their Israeli occupiers, and their willingness to attack innocent civilians is wrong. This behavior is not surprising, however, because the Palestinians believe they have no other way to force Israeli concessions. As former Prime Minister Barak once admitted, had he been born a Palestinian, he "would have joined a terrorist organization." 55

Finally, we should not forget that the Zionists used terrorism when they were in a similarly weak position and trying to obtain their own state. Between 1944 and 1947, several Zionist organizations used terrorist bombings to drive the British from Palestine, and took the lives of many innocent civilians along the way. ${ }^{56}$ Israeli terrorists also murdered U.N. mediator Count Folke Bernadotte in 1948, because they opposed his proposal to internationalize Jerusalem. ${ }^{57}$ Nor were the perpetrators of these acts isolated extremists: the leaders of the murder plot were eventually granted amnesty by the Israeli government and one of them was elected to the Knesset. Another terrorist leader, who approved the murder but was not tried, was future Prime Minister Yitzhak Shamir. Indeed, Shamir openly argued that "neither Jewish ethics nor Jewish tradition can disqualify terrorism as a means of combat." Rather, terrorism had "a great part to play ... in our war against the occupier [Britain]." 58 If the Palestinians' use of terrorism is morally reprehensible today, so was Israel's reliance upon it in the past, and thus one cannot justify U.S. support for Israel on the grounds that its past conduct was morally superior. ${ }^{59}$ 
Israel may not have acted worse than many other countries, but it clearly has not acted any better. And if neither strategic nor moral arguments can account for America's support for Israel, how are we to explain it?

\section{THE ISRAEL LOBBY}

The explanation lies in the unmatched power of the Israel Lobby. Were it not for the Lobby's ability to manipulate the American political system, the relationship between Israel and the United States would be far less intimate than it is today.

\section{What Is The Lobby?}

We use "the Lobby" as a convenient short-hand term for the loose coalition of individuals and organizations who actively work to shape U.S. foreign policy in a pro-Israel direction. Our use of this term is not meant to suggest that "the Lobby" is a unified movement with a central leadership, or that individuals within it do not disagree on certain issues

The core of the Lobby is comprised of American Jews who make a significant effort in their daily lives to bend U.S. foreign policy so that it advances Israel's interests. Their activities go beyond merely voting for candidates who are proIsrael to include letter-writing, financial contributions, and supporting pro-Israel organizations. But not all Jewish-Americans are part of the Lobby, because Israel is not a salient issue for many of them. In a 2004 survey, for example, roughly 36 percent of Jewish-Americans said they were either "not very" or "not at all" emotionally attached to Israel. ${ }^{60}$

Jewish-Americans also differ on specific Israeli policies. Many of the key organizations in the Lobby, like AIPAC and the Conference of Presidents of Major Jewish Organizations (CPMJO), are run by hardliners who generally supported the expansionist policies of Israel's Likud Party, including its hostility to the Oslo Peace Process. The bulk of U.S. Jewry, on the other hand, is more favorably disposed to making concessions to the Palestinians, and a few groups-such as Jewish Voice for Peace-strongly advocate such steps. ${ }^{61}$ Despite these differences, moderates and hardliners both support steadfast U.S. support for Israel.

Not surprisingly, American Jewish leaders often consult with Israeli officials, so that the former can maximize their influence in the United States. As one activist with a major Jewish organization wrote, "it is routine for us to say: 'This is our 
policy on a certain issue, but we must check what the Israelis think.' We as a community do it all the time." 62 There is also a strong norm against criticizing Israeli policy, and Jewish-American leaders rarely support putting pressure on Israel. Thus, Edgar Bronfman Sr., the president of the World Jewish Congress, was accused of "perfidy" when he wrote a letter to President Bush in mid-2003 urging Bush to pressure Israel to curb construction of its controversial "security fence." ${ }^{63}$ Critics declared that, "It would be obscene at any time for the president of the World Jewish Congress to lobby the president of the United States to resist policies being promoted by the government of Israel."

Similarly, when Israel Policy Forum president Seymour Reich advised Secretary of State Condoleezza Rice to pressure Israel to reopen a critical border crossing in the Gaza Strip in November 2005, critics denounced his action as "irresponsible behavior," and declared that, "There is absolutely no room in the Jewish mainstream for actively canvassing against the security-related policies ... of Israel." ${ }^{64}$ Recoiling from these attacks, Reich proclaimed that "the word pressure is not in my vocabulary when it comes to Israel."

Jewish-Americans have formed an impressive array of organizations to influence American foreign policy, of which AIPAC is the most powerful and well-known. In 1997, Fortune magazine asked members of Congress and their staffs to list the most powerful lobbies in Washington. ${ }^{65}$ AIPAC was ranked second behind the American Association of Retired People (AARP), but ahead of heavyweight lobbies like the AFL-CIO and the National Rifle Association. A National Journal study in March 2005 reached a similar conclusion, placing AIPAC in second place (tied with AARP) in the Washington's "muscle rankings." ${ }^{66}$

The Lobby also includes prominent Christian evangelicals like Gary Bauer, Jerry Falwell, Ralph Reed, and Pat Robertson, as well as Dick Armey and Tom DeLay, former majority leaders in the House of Representatives. They believe Israel's rebirth is part of Biblical prophecy, support its expansionist agenda, and think pressuring Israel is contrary to God's will. ${ }^{67}$ In addition, the Lobby's membership includes neoconservative gentiles such as John Bolton, the late Wall Street Journal editor Robert Bartley, former Secretary of Education William Bennett, former U.N. Ambassador Jeanne Kirkpatrick, and columnist George Will. 


\section{Sources of Power}

The United States has a divided government that offers many ways to influence the policy process. As a result, interest groups can shape policy in many different ways - by lobbying elected representatives and members of the executive branch, making campaign contributions, voting in elections, molding public opinion, etc.

Furthermore, special interest groups enjoy disproportionate power when they are committed to a particular issue and the bulk of the population is indifferent. Policymakers will tend to accommodate those who care about the issue in question, even if their numbers are small, confident that the rest of the population will not penalize them.

The Israel Lobby's power flows from its unmatched ability to play this game of interest group politics. In its basic operations, it is no different from interest groups like the Farm Lobby, steel and textile workers, and other ethnic lobbies. What sets the Israel Lobby apart is its extraordinary effectiveness. But there is nothing improper about American Jews and their Christian allies attempting to sway U.S. policy towards Israel. The Lobby's activities are not the sort of conspiracy depicted in anti-Semitic tracts like the Protocols of the Elders of Zion. For the most part, the individuals and groups that comprise the Lobby are doing what other special interest groups do, just much better. Moreover, pro-Arab interest groups are weak to non-existent, which makes the Lobby's task even easier. $^{68}$

\section{Strategies for Success}

The Lobby pursues two broad strategies to promote U.S. support for Israel. First, it wields significant influence in Washington, pressuring both Congress and the Executive branch to support Israel down the line. Whatever an individual lawmaker or policymaker's own views, the Lobby tries to make supporting Israel the "smart" political choice.

Second, the Lobby strives to ensure that public discourse about Israel portrays it in a positive light, by repeating myths about Israel and its founding and by publicizing Israel's side in the policy debates of the day. The goal is to prevent critical commentary about Israel from getting a fair hearing in the political arena. Controlling the debate is essential to guaranteeing U.S. support, because a 
candid discussion of U.S.-Israeli relations might lead Americans to favor a different policy.

\section{Influencing Congress}

A key pillar of the Lobby's effectiveness is its influence in the U.S. Congress, where Israel is virtually immune from criticism. This is in itself a remarkable situation, because Congress almost never shies away from contentious issues. Whether the issue is abortion, affirmative action, health care, or welfare, there is certain to be a lively debate on Capitol Hill. Where Israel is concerned, however, potential critics fall silent and there is hardly any debate at all.

One reason for the Lobby's success with Congress is that some key members are Christian Zionists like Dick Armey, who said in September 2002 that "My No. 1 priority in foreign policy is to protect Israel." ${ }^{69}$ One would think that the number 1 priority for any congressman would be to "protect America," but that is not what Armey said. There are also Jewish senators and congressmen who work to make U.S. foreign policy support Israel's interests.

Pro-Israel congressional staffers are another source of the Lobby's power. As Morris Amitay, a former head of AIPAC, once admitted, "There are a lot of guys at the working level up here [on Capitol Hill] ... who happen to be Jewish, who are willing ... to look at certain issues in terms of their Jewishness .... These are all guys who are in a position to make the decision in these areas for those senators .... You can get an awful lot done just at the staff level." ${ }^{70}$

It is AIPAC itself, however, that forms the core of the Lobby's influence in Congress. AIPAC's success is due to its ability to reward legislators and congressional candidates who support its agenda, and to punish those who challenge it. Money is critical to U.S. elections (as the recent scandal over lobbyist Jack Abramoff's various shady dealings reminds us), and AIPAC makes sure that its friends get strong financial support from the myriad pro-Israel political action committees. Those seen as hostile to Israel, on the other hand, can be sure that AIPAC will direct campaign contributions to their political opponents. AIPAC also organizes letter-writing campaigns and encourages newspaper editors to endorse pro-Israel candidates.

There is no doubt about the potency of these tactics. To take but one example, in 1984 AIPAC helped defeat Senator Charles Percy from Illinois, who, according to one prominent Lobby figure, had "displayed insensitivity and even hostility to 
our concerns." Thomas Dine, the head of AIPAC at the time, explained what happened: "All the Jews in America, from coast to coast, gathered to oust Percy. And the American politicians -- those who hold public positions now, and those who aspire -- got the message." 71 AIPAC prizes its reputation as a formidable adversary, of course, because it discourages anyone from questioning its agenda.

AIPAC's influence on Capitol Hill goes even further, however. According to Douglas Bloomfield, a former AIPAC staff member, "It is common for members of Congress and their staffs to turn to AIPAC first when they need information, before calling the Library of Congress, the Congressional Research Service, committee staff or administration experts." ${ }^{72}$ More importantly, he notes that AIPAC is "often called upon to draft speeches, work on legislation, advise on tactics, perform research, collect co-sponsors and marshal votes."

The bottom line is that AIPAC, which is a de facto agent for a foreign government, has a stranglehold on the U.S. Congress. ${ }^{73}$ Open debate about U.S. policy towards Israel does not occur there, even though that policy has important consequences for the entire world. Thus, one of the three main branches of the U.S. government is firmly committed to supporting Israel. As former Senator Ernest Hollings (D-SC) noted as he was leaving office, "You can't have an Israeli policy other than what AIPAC gives you around here."74 Small wonder that Israeli Prime Minister Ariel Sharon once told an American audience. "When people ask me how they can help Israel, I tell them-Help AIPAC."75

\section{Influencing the Executive}

The Lobby also has significant leverage over the Executive branch. That power derives in part from the influence Jewish voters have on presidential elections. Despite their small numbers in the population (less than 3 percent), they make large campaign donations to candidates from both parties. The Washington Post once estimated that Democratic presidential candidates "depend on Jewish supporters to supply as much as 60 percent of the money."76 Furthermore, Jewish voters have high turn-out rates and are concentrated in key states like California, Florida, Illinois, New York, and Pennsylvania. Because they matter in close elections, Presidential candidates go to great lengths not to antagonize Jewish voters.

Key organizations in the Lobby also directly target the administration in power. For example, pro-Israel forces make sure that critics of the Jewish state do not get important foreign-policy appointments. Jimmy Carter wanted to make George 
Ball his first secretary of state, but he knew that Ball was perceived as critical of Israel and that the Lobby would oppose the appointment. ${ }^{77}$ This litmus test forces any aspiring policymaker to become an overt supporter of Israel, which is why public critics of Israeli policy have become an endangered species in the U.S. foreign policy establishment.

These constraints still operate today. When 2004 presidential candidate Howard Dean called for the United States to take a more "even-handed role" in the ArabIsraeli conflict, Senator Joseph Lieberman accused him of selling Israel down the river and said his statement was "irresponsible."78 Virtually all of the top Democrats in the House signed a hard-hitting letter to Dean criticizing his comments, and the Chicago Jewish Star reported that "anonymous attackers ... are clogging the e-mail inboxes of Jewish leaders around the country, warning -without much evidence -- that Dean would somehow be bad for Israel." 79

This worry was absurd, however, because Dean is in fact quite hawkish on Israel..$^{80}$ His campaign co-chair was a former AIPAC president, and Dean said his own views on the Middle East more closely reflected those of AIPAC than the more moderate Americans for Peace Now. Dean had merely suggested that to "bring the sides together," Washington should act as an honest broker. This is hardly a radical idea, but it is anathema to the Lobby, which does not tolerate the idea of even-handedness when it comes to the Arab-Israeli conflict.

The Lobby's goals are also served when pro-Israel individuals occupy important positions in the executive branch. During the Clinton Administration, for example, Middle East policy was largely shaped by officials with close ties to Israel or to prominent pro-Israel organizations-including Martin Indyk, the former deputy director of research at AIPAC and co-founder of the pro-Israel Washington Institute for Near East Policy (WINEP); Dennis Ross, who joined WINEP after leaving government in 2001; and Aaron Miller, who has lived in Israel and often visits there. ${ }^{81}$

These men were among President Clinton's closest advisors at the Camp David summit in July 2000. Although all three supported the Oslo peace process and favored creation of a Palestinian state, they did so only within the limits of what would be acceptable to Israel..$^{82}$ In particular, the American delegation took its cues from Israeli Prime Minister Ehud Barak, coordinated negotiating positions in advance, and did not offer its own independent proposals for settling the conflict. Not surprisingly, Palestinian negotiators complained that they were 
"negotiating with two Israeli teams -- one displaying an Israeli flag, and one an American flag." 83

The situation is even more pronounced in the Bush Administration, whose ranks include fervently pro-Israel individuals like Elliot Abrams, John Bolton, Douglas Feith, I. Lewis ("Scooter") Libby, Richard Perle, Paul Wolfowitz, and David Wurmser. As we shall see, these officials consistently pushed for policies favored by Israel and backed by organizations in the Lobby.

\section{Manipulating the Media}

In addition to influencing government policy directly, the Lobby strives to shape public perceptions about Israel and the Middle East. It does not want an open debate on issues involving Israel, because an open debate might cause Americans to question the level of support that they currently provide. Accordingly, proIsrael organizations work hard to influence the media, think tanks, and academia, because these institutions are critical in shaping popular opinion.

The Lobby's perspective on Israel is widely reflected in the mainstream media in good part because most American commentators are pro-Israel. The debate among Middle East pundits, journalist Eric Alterman writes, is "dominated by people who cannot imagine criticizing Israel." ${ }^{84}$ He lists 61 "columnists and commentators who can be counted upon to support Israel reflexively and without qualification." Conversely, Alterman found just five pundits who consistently criticize Israeli behavior or endorse pro-Arab positions. Newspapers occasionally publish guest op-eds challenging Israeli policy, but the balance of opinion clearly favors the other side.

This pro-Israel bias is reflected in the editorials of major newspapers. Robert Bartley, the late editor of the Wall Street Journal, once remarked that, "Shamir, Sharon, Bibi - whatever those guys want is pretty much fine by me." 85 Not surprisingly, the Journal, along with other prominent newspapers like The Chicago Sun-Times and The Washington Times regularly run editorials that are strongly pro-Israel. Magazines like Commentary, the New Republic, and the Weekly Standard also zealously defend Israel at every turn.

Editorial bias is also found in papers like the New York Times. The Times occasionally criticizes Israeli policies and sometimes concedes that the Palestinians have legitimate grievances, but it is not even-handed. In his memoirs, for example, former Times executive editor Max Frankel acknowledged 
the impact his own pro-Israel attitude had on his editorial choices. In his words: "I was much more deeply devoted to Israel than I dared to assert." He goes on: "Fortified by my knowledge of Israel and my friendships there, I myself wrote most of our Middle East commentaries. As more Arab than Jewish readers recognized, I wrote them from a pro-Israel perspective." 86

The media's reporting of news events involving Israel is somewhat more evenhanded than editorial commentary is, in part because reporters strive to be objective, but also because it is difficult to cover events in the occupied territories without acknowledging Israel's actual behavior. To discourage unfavorable reporting on Israel, the Lobby organizes letter writing campaigns, demonstrations, and boycotts against news outlets whose content it considers anti-Israel. One CNN executive has said that he sometimes gets 6,000 e-mail messages in a single day complaining that a story is anti-Israel. ${ }^{87}$ Similarly, the pro-Israel Committee for Accurate Middle East Reporting in America (CAMERA) organized demonstrations outside National Public Radio stations in 33 cities in May 2003, and it also tried to convince contributors to withhold support from NPR until its Middle East coverage became more sympathetic to Israel. ${ }^{88}$ Boston's NPR station, WBUR, reportedly lost more than $\$ 1$ million in contributions as a result of these efforts. Pressure on NPR has also come from Israel's friends in Congress, who have asked NPR for an internal audit as well as more oversight of its Middle East coverage.

These factors help explain why the American media contains few criticisms of Israeli policy, rarely questions Washington's relationship with Israel, and only occasionally discusses the Lobby's profound influence on U.S. policy.

\section{Think Tanks That Think One Way}

Pro-Israel forces predominate in U.S. think tanks, which play an important role in shaping public debate as well as actual policy. The Lobby created its own think tank in 1985, when Martin Indyk helped found WINEP. ${ }^{89}$ Although WINEP plays down its links to Israel and claims instead that it provides a "balanced and realistic" perspective on Middle East issues, this is not the case. ${ }^{90}$ In fact, WINEP is funded and run by individuals who are deeply committed to advancing Israel's agenda.

The Lobby's influence in the think tank world extends well beyond WINEP. Over the past 25 years, pro-Israel forces have established a commanding

presence at the American Enterprise Institute, the Brookings Institution, the 
Center for Security Policy, the Foreign Policy Research Institute, the Heritage Foundation, the Hudson Institute, the Institute for Foreign Policy Analysis, and the Jewish Institute for National Security Affairs (JINSA). These think tanks are decidedly pro-Israel, and include few, if any, critics of U.S. support for the Jewish state.

A good indicator of the Lobby's influence in the think tank world is the evolution of the Brookings Institution. For many years, its senior expert on Middle East issues was William B. Quandt, a distinguished academic and former NSC official with a well-deserved reputation for evenhandedness regarding the Arab-Israeli conflict. Today, however, Brookings's work on these issues is conducted through its Saban Center for Middle East Studies, which is financed by Haim Saban, a wealthy Israeli-American businessman and ardent Zionist. ${ }^{91}$ The director of the Saban Center is the ubiquitous Martin Indyk. Thus, what was once a non-partisan policy institute on Middle East matters is now part of the chorus of largely pro-Israel think tanks.

\section{Policing Academia}

The Lobby has had the most difficulty stifling debate about Israel on college campuses, because academic freedom is a core value and because tenured professors are hard to threaten or silence. Even so, there was only mild criticism of Israel in the 1990s, when the Oslo peace process was underway. Criticism rose after that process collapsed and Ariel Sharon came to power in early 2001, and it became especially intense when the IDF re-occupied the West Bank in spring 2002 and employed massive force against the Second Intifada.

The Lobby moved aggressively to "take back the campuses." New groups sprang up, like the Caravan for Democracy, which brought Israeli speakers to U.S. colleges. ${ }^{92}$ Established groups like the Jewish Council for Public Affairs and Hillel jumped into the fray, and a new group - the Israel on Campus Coalitionwas formed to coordinate the many groups that now sought to make Israel's case on campus. Finally, AIPAC more than tripled its spending for programs to monitor university activities and to train young advocates for Israel, in order to "vastly expand the number of students involved on campus ... in the national pro-Israel effort." 93

The Lobby also monitors what professors write and teach. In September 2002, for example, Martin Kramer and Daniel Pipes, two passionately pro-Israel neoconservatives, established a website (Campus Watch) that posted dossiers on 
suspect academics and encouraged students to report comments or behavior that might be considered hostile to Israel..$^{94}$ This transparent attempt to blacklist and intimidate scholars prompted a harsh reaction and Pipes and Kramer later removed the dossiers, but the website still invites students to report alleged antiIsrael behavior at U.S. colleges.

Groups in the Lobby also direct their fire at particular professors and the universities that hire them. Columbia University, which had the late Palestinian scholar Edward Said on its faculty, has been a frequent target of pro-Israel forces. Jonathan Cole, the former Columbia provost, reported that, "One can be sure that any public statement in support of the Palestinian people by the preeminent literary critic Edward Said will elicit hundreds of e-mails, letters, and journalistic accounts that call on us to denounce Said and to either sanction or fire him." ${ }^{\prime 95}$ When Columbia recruited historian Rashid Khalidi from the University of Chicago, Cole says that "the complaints started flowing in from people who disagreed with the content of his political views." Princeton faced the same problem a few years later when it considered wooing Khalidi away from Columbia. ${ }^{96}$

A classic illustration of the effort to police academia occurred in late 2004, when the "David Project" produced a propaganda film alleging that faculty in Columbia University's Middle East studies program were anti-Semitic and were intimidating Jewish students who defended Israel. ${ }^{97}$ Columbia was raked over the coals in pro-Israel circles, but a faculty committee assigned to investigate the charges found no evidence of anti-Semitism and the only incident worth noting was the possibility that one professor had "responded heatedly" to a student's question..$^{98}$ The committee also discovered that the accused professors had been the target of an overt intimidation campaign.

Perhaps the most disturbing aspect of this campaign to eliminate criticism of Israel from college campuses is the effort by Jewish groups to push Congress to establish mechanisms that monitor what professors say about Israel. ${ }^{99}$ Schools judged to have an anti-Israel bias would be denied Federal funding. This effort to get the U.S. government to police campuses have not yet succeeded, but the attempt illustrates the importance pro-Israel groups place on controlling debate on these issues.

Finally, a number of Jewish philanthropists have established Israel studies programs (in addition to the roughly 130 Jewish Studies programs that already exist) so as to increase the number of Israel-friendly scholars on campus. ${ }^{100}$ NYU 
announced the establishment of the Taub Center for Israel Studies on May 1, 2003, and similar programs have been established at other schools like Berkeley, Brandeis, and Emory. Academic administrators emphasize the pedagogical value of these programs, but the truth is that they are intended in good part to promote Israel's image on campus. Fred Laffer, the head of the Taub Foundation, makes clear that his foundation funded the NYU center to help counter the "Arabic [sic] point of view" that he thinks is prevalent in NYU's Middle East programs. ${ }^{101}$

In sum, the Lobby has gone to considerable lengths to insulate Israel from criticism on college campuses. It has not been as successful in academia as it has been on Capitol Hill, but it has worked hard to stifle criticism of Israel by professors and students and there is much less of it on campuses today. ${ }^{102}$

\section{The Great Silencer}

No discussion of how the Lobby operates would be complete without examining one of its most powerful weapons: the charge of anti-Semitism. Anyone who criticizes Israeli actions or says that pro-Israel groups have significant influence over U.S. Middle East policy - an influence that AIPAC celebrates - stands a good chance of getting labeled an anti-Semite. In fact, anyone who says that there is an Israel Lobby runs the risk of being charged with anti-Semitism, even though the Israeli media themselves refer to America's "Jewish Lobby." In effect, the Lobby boasts of its own power and then attacks anyone who calls attention to it. This tactic is very effective, because anti-Semitism is loathsome and no responsible person wants to be accused of it.

Europeans have been more willing than Americans to criticize Israeli policy in recent years, which some attribute to a resurgence of anti-Semitism in Europe. We are "getting to a point," the U.S. Ambassador to the European Union said in early 2004, "where it is as bad as it was in the 1930s." 103 Measuring anti-Semitism is a complicated matter, but the weight of evidence points in the opposite direction. For example, in the spring of 2004, when accusations of European antiSemitism filled the air in America, separate surveys of European public opinion conducted by the Anti-Defamation League and the Pew Research Center for the People and the Press showed that it was actually declining. ${ }^{104}$

Consider France, which pro-Israel forces often portray as the most anti-Semitic state in Europe. A poll of French citizens in 2002 found that: 89 percent could envisage living with a Jew; 97 percent believe making anti-Semitic graffiti is a 
serious crime; 87 percent think attacks on French synagogues are scandalous; and 85 percent of practicing French Catholics reject the charge that Jews have too much influence in business and finance. ${ }^{105}$ It is unsurprising that the head of the French Jewish community declared in the summer of 2003 that "France is not more anti-Semitic than America." 106 According to a recent article in $\mathrm{Ha}^{\prime}$ aretz, the French police report that anti-Semitic incidents in France declined by almost 50 per cent in 2005; and this despite the fact that France has the largest Muslim population of any country in Europe. ${ }^{107}$

Finally, when a French Jew was brutally murdered last month by a Muslim gang, tens of thousands of French demonstrators poured into the streets to condemn anti-Semitism. Moreover, President Jacques Chirac and Prime Minister Dominique de Villepin both attended the victim's memorial service in a public show of solidarity with French Jewry. ${ }^{108}$ It is also worth noting that in 2002 more Jews immigrated to Germany than Israel, making it "the fastest growing Jewish community in the world," according to an article in the Jewish newspaper Forward. ${ }^{109}$ If Europe were really heading back to the 1930s, it is hard to imagine that Jews would be moving there in large numbers.

We recognize, however, that Europe is not free of the scourge of anti-Semitism. No one would deny that there are still some virulent autochthonous anti-Semites in Europe (as there are in the United States) but their numbers are small and their extreme views are rejected by the vast majority of Europeans. Nor would one deny that there is anti-Semitism among European Muslims, some of it provoked by Israel's behavior towards the Palestinians and some of it straightforwardly racist. ${ }^{110}$ This problem is worrisome, but it is hardly out of control. Muslims constitute less than five percent of Europe's total population, and European governments are working hard to combat the problem. Why? Because most Europeans reject such hateful views. ${ }^{111}$ In short, when it comes to anti-Semitism, Europe today bears hardly any resemblance to Europe in the 1930s.

This is why pro-Israel forces, when pressed to go beyond assertion, claim that there is a 'new anti-Semitism', which they equate with criticism of Israel. ${ }^{112}$ In other words criticize Israeli policy and you are by definition an anti-Semite. When the synod of the Church of England recently voted to divest from Caterpillar Inc on the grounds that Caterpillar manufactures the bulldozers used to demolish Palestinian homes, the Chief Rabbi complained that it would 'have the most adverse repercussions on ... Jewish-Christian relations in Britain', while Rabbi Tony Bayfield, the head of the Reform movement, said: “'There is a clear problem of anti-Zionist - verging on anti-Semitic - attitudes emerging in the grass 
roots, and even in the middle ranks of the Church."113 However, the Church was neither guilty of anti-Zionism nor anti-Semitism; it was merely protesting Israeli policy. ${ }^{114}$

Critics are also accused of holding Israel to an unfair standard or questioning its right to exist. But these are bogus charges too. Western critics of Israel hardly ever question its right to exist. Instead, they question its behavior towards the Palestinians, which is a legitimate criticism: Israelis question it themselves. Nor is Israel being judged unfairly. Rather, Israeli treatment of the Palestinians elicits criticism because it is contrary to widely-accepted human rights norms and international law, as well as the principle of national self-determination. And it is hardly the only state that has faced sharp criticism on these grounds.

In sum, other ethnic lobbies can only dream of having the political muscle that pro-Israel organizations possess. The question, therefore, is what effect does the Lobby have on U.S. foreign policy?

\section{THE TAIL WAGGING THE DOG}

If the Lobby's impact were confined to U.S. economic aid to Israel, its influence might not be that worrisome. Foreign aid is valuable, but not as useful as having the world's only superpower bring its vast capabilities to bear on Israel's behalf. Accordingly, the Lobby has also sought to shape the core elements of U.S. Middle East policy. In particular, it has worked successfully to convince American leaders to back Israel's continued repression of the Palestinians and to take aim at Israel's primary regional adversaries: Iran, Iraq, and Syria.

\section{Demonizing the Palestinians}

It is now largely forgotten, but in the fall of 2001, and especially in the spring of 2002, the Bush Administration tried to reduce anti-American sentiment in the Arab world and undermine support for terrorist groups like al Qaeda, by halting Israel's expansionist policies in the occupied territories and advocating the creation of a Palestinian state.

Bush had enormous potential leverage at his disposal. He could have threatened to reduce U.S. economic and diplomatic support for Israel, and the American people would almost certainly have supported him. A May 2003 poll reported that over 60 percent of Americans were willing to withhold aid to Israel if it resisted U.S. pressure to settle the conflict, and that number rose to 70 percent 
among "politically active" Americans. ${ }^{115}$ Indeed, 73 percent said that United States should not favor either side.

Yet the Bush Administration failed to change Israel's policies, and Washington ended up backing Israel's hard-line approach instead. Over time, the Administration also adopted Israel's justifications for this approach, so that U.S. and Israeli rhetoric became similar. By February 2003, a Washington Post headline summarized the situation: "Bush and Sharon Nearly Identical on Mideast Policy."116 The main reason for this switch is the Lobby.

The story begins in late September 2001 when President Bush began pressuring Israeli Prime Minister Sharon to show restraint in the occupied territories. He also pressed Sharon to allow Israeli foreign minister Shimon Peres to meet with Palestinian leader Yasser Arafat, even though Bush was highly critical of Arafat's leadership. ${ }^{117}$ Bush also said publicly that he supported a Palestinian state. ${ }^{118}$ Alarmed by these developments, Sharon accused Bush of trying "to appease the Arabs at our expense," warning that Israel "will not be Czechoslovakia."119

Bush was reportedly furious at Sharon's likening him to Neville Chamberlain, and White House press secretary Ari Fleischer called Sharon's remarks "unacceptable." 120 The Israeli prime minister offered a pro forma apology, but he quickly joined forces with the Lobby to convince the Bush administration and the American people that the United States and Israel faced a common threat from terrorism. ${ }^{121}$ Israeli officials and Lobby representatives repeatedly emphasized that there was no real difference between Arafat and Osama bin Laden, and insisted that the United States and Israel should isolate the Palestinians' elected leader and have nothing to do with him. ${ }^{122}$

The Lobby also went to work in Congress. On November 16, 89 senators sent Bush a letter praising him for refusing to meet with Arafat, but also demanding that the United States not restrain Israel from retaliating against the Palestinians and insisting that the administration state publicly that it stood steadfastly behind Israel. According to the New York Times, the letter "stemmed from a meeting two weeks ago between leaders of the American Jewish community and key senators," adding that AIPAC was "particularly active in providing advice on the letter." 123

By late November, relations between Tel Aviv and Washington had improved considerably. This was due in part to the Lobby's efforts to bend U.S. policy in Israel's direction, but also to America's initial victory in Afghanistan, which 
reduced the perceived need for Arab support in dealing with al Qaeda. Sharon visited the White House in early December and had a friendly meeting with Bush. ${ }^{124}$

But trouble erupted again in April 2002, after the IDF launched Operation Defensive Shield and resumed control of virtually all of the major Palestinian areas on the West Bank. ${ }^{125}$ Bush knew that Israel's action would damage America's image in the Arab and Islamic world and undermine the war on terrorism, so he demanded on April 4 that Sharon "halt the incursions and begin withdrawal." He underscored this message two days later, saying this meant "withdrawal without delay." On April 7, Bush's national security advisor, Condoleezza Rice, told reporters that, "'without delay' means without delay. It means now." That same day Secretary of State Colin Powell set out for the Middle East to pressure all sides to stop fighting and start negotiating. ${ }^{126}$

Israel and the Lobby swung into action. A key target was Powell, who began feeling intense heat from pro-Israel officials in Vice President Cheney's office and the Pentagon, as well as from neoconservative pundits like Robert Kagan and William Kristol, who accused him of having "virtually obliterated the distinction between terrorists and those fighting terrorists." ${ }^{127}$ A second target was Bush himself, who was being pressed by Jewish leaders and Christian evangelicals, the latter a key component of his political base. Tom DeLay and Dick Armey were especially outspoken about the need to support Israel, and DeLay and Senate Minority Leader Trent Lott visited the White House and personally warned Bush to back off. ${ }^{128}$

The first sign that Bush was caving came on April 11-only one week after he told Sharon to withdraw his forces - when Ari Fleischer said the President believes Sharon is "a man of peace." 129 Bush repeated this statement publicly upon Powell's return from his abortive mission, and he told reporters that Sharon had responded satisfactorily to his call for a full and immediate withdrawal. ${ }^{130}$ Sharon had done no such thing, but the President of the United States was no longer willing to make an issue of it.

Meanwhile, Congress was also moving to back Sharon. On May 2, it overrode the Administration's objections and passed two resolutions reaffirming support for Israel. (The Senate vote was 94 to 2; the House version passed 352-21). Both resolutions emphasized that the United States "stands in solidarity with Israel" and that the two countries are, to quote the House resolution, "now engaged in a common struggle against terrorism." The House version also condemned "the 
ongoing support of terror by Yasir Arafat," who was portrayed as a central element of the terrorism problem. ${ }^{131}$ A few days later, a bipartisan congressional delegation on a fact-finding mission in Israel publicly proclaimed that Sharon should resist U.S. pressure to negotiate with Arafat. ${ }^{132}$ On May 9, a House appropriations subcommittee met to consider giving Israel an extra \$200 million to fight terrorism. Secretary of State Powell opposed the package, but the Lobby backed it, just as it had helped author the two congressional resolutions. ${ }^{133}$ Powell lost.

In short, Sharon and the Lobby took on the President of the United States and triumphed. Hemi Shalev, a journalist for the Israel newspaper Ma'ariv, reported that Sharon's aides "could not hide their satisfaction in view of Powell's failure. Sharon saw the white in President Bush's eyes, they bragged, and the President blinked first." ${ }^{134}$ But it was the pro-Israel forces in the United States, not Sharon or Israel, that played the key role in defeating Bush.

The situation has changed little since then. The Bush Administration refused to deal further with Arafat, who eventually died in November 2004. It has subsequently embraced the new Palestinian leader, Mahmoud Abbas, but has done little to help him gain a viable state. Sharon continued to develop his plans for unilateral "disengagement" from the Palestinians, based on withdrawal from Gaza coupled with continued expansion on the West Bank, which entails building the so-called "security fence," seizing Palestinian-owned land, and expanding settlement blocs and road networks. By refusing to negotiate with Abbas (who favors a negotiated settlement) and making it impossible for him to deliver tangible benefits to the Palestinian people, Sharon's strategy contributed directly to Hamas' recent electoral victory. ${ }^{135}$ With Hamas in power, however, Israel has another excuse not to negotiate. The administration has supported Sharon's actions (and those of his successor, Ehud Olmert), and Bush has even endorsed unilateral Israeli annexations in the Occupied Territories, reversing the stated policy of every president since Lyndon Johnson. ${ }^{136}$

U.S. officials have offered mild criticisms of a few Israeli actions, but have done little to help create a viable Palestinian state. Former national security advisor Brent Scowcroft even declared in October 2004 that Sharon has President Bush "wrapped around his little finger."137 If Bush tries to distance the United States from Israel, or even criticizes Israeli actions in the occupied territories, he is certain to face the wrath of the Lobby and its supporters in Congress.

Democratic Party presidential candidates understand these facts of life too, 
which is why John Kerry went to great lengths to display his unalloyed support for Israel in 2004 and why Hillary Clinton is doing the same thing today. ${ }^{138}$

Maintaining U.S. support for Israel's policies against the Palestinians is a core goal of the Lobby, but its ambitions do not stop there. It also wants America to help Israel remain the dominant regional power. Not surprisingly, the Israeli government and pro-Israel groups in the United States worked together to shape the Bush Administration's policy towards Iraq, Syria, and Iran, as well as its grand scheme for reordering the Middle East.

\section{Israel and the Iraq War}

Pressure from Israel and the Lobby was not the only factor behind the U.S. decision to attack Iraq in March 2003, but it was a critical element. Some Americans believe that this was a "war for oil," but there is hardly any direct evidence to support this claim. Instead, the war was motivated in good part by a desire to make Israel more secure. According to Philip Zelikow, a member of the President's Foreign Intelligence Advisory Board (2001-2003), executive director of the 9/11 Commission, and now Counselor to Secretary of State Condoleezza Rice, the "real threat" from Iraq was not a threat to the United States. ${ }^{139}$ The "unstated threat" was the "threat against Israel," Zelikow told a University of Virginia audience in September 2002, noting further that "the American government doesn't want to lean too hard on it rhetorically, because it is not a popular sell."

On August 16, 2002, eleven days before Vice President Cheney kicked off the campaign for war with a hard-line speech to the Veterans of Foreign Wars, the Washington Post reported that "Israel is urging U.S. officials not to delay a military strike against Iraq's Saddam Hussein." ${ }^{140}$ By this point, according to Sharon, strategic coordination between Israel and the U.S. had reached "unprecedented dimensions," and Israeli intelligence officials had given Washington a variety of alarming reports about Iraq's WMD programs. ${ }^{141}$ As one retired Israeli general later put it, "Israeli intelligence was a full partner to the picture presented by American and British intelligence regarding Iraq's nonconventional capabilities." ${ }^{142}$

Israeli leaders were deeply distressed when President Bush decided to seek U.N. Security Council authorization for war in September, and even more worried when Saddam agreed to let U.N. inspectors back into Iraq, because these developments seemed to reduce the likelihood of war. Foreign Minister Shimon 
Peres told reporters in September 2002 that "the campaign against Saddam Hussein is a must. Inspections and inspectors are good for decent people, but dishonest people can overcome easily inspections and inspectors." 143

At the same time, former Prime Minister Ehud Barak wrote a New York Times oped warning that "the greatest risk now lies in inaction." 144 His predecessor, Benjamin Netanyahu, published a similar piece in the Wall Street Journal entitled "The Case for Toppling Saddam." 145 Netanyahu declared, "Today nothing less than dismantling his regime will do," adding that "I believe I speak for the overwhelming majority of Israelis in supporting a pre-emptive strike against Saddam's regime." Or as Ha'aretz reported in February 2003: “The [Israeli] military and political leadership yearns for war in Iraq." 146

But as Netanyahu suggests, the desire for war was not confined to Israel's leaders. Apart from Kuwait, which Saddam conquered in 1990, Israel was the only country in the world where both the politicians and the public enthusiastically favored war. ${ }^{147}$ As journalist Gideon Levy observed at the time, "Israel is the only country in the West whose leaders support the war unreservedly and where no alternative opinion is voiced." 148 In fact, Israelis were so gung-ho for war that their allies in America told them to damp down their hawkish rhetoric, lest it look like the war was for Israel. ${ }^{149}$

\section{The Lobby and the Iraq War}

Within the United States, the main driving force behind the Iraq war was a small band of neoconservatives, many with close ties to Israel's Likud Party. ${ }^{150}$ In addition, key leaders of the Lobby's major organizations lent their voices to the campaign for war. ${ }^{151}$ According to the Forward, "As President Bush attempted to sell the ... war in Iraq, America's most important Jewish organizations rallied as one to his defense. In statement after statement community leaders stressed the need to rid the world of Saddam Hussein and his weapons of mass destruction." 152 The editorial goes on to say that "concern for Israel's safety rightfully factored into the deliberations of the main Jewish groups."

Although neoconservatives and other Lobby leaders were eager to invade Iraq, the broader American Jewish community was not. ${ }^{153}$ In fact, Samuel Freedman reported just after the war started that "a compilation of nationwide opinion polls by the Pew Research Center shows that Jews are less supportive of the Iraq war than the population at large, $52 \%$ to $62 \%$." 154 Thus, it would be wrong to 
blame the war in Iraq on "Jewish influence." Rather, the war was due in large part to the Lobby's influence, especially the neoconservatives within it.

The neoconservatives were already determined to topple Saddam before Bush became President. ${ }^{155}$ They caused a stir in early 1998 by publishing two open letters to President Clinton calling for Saddam's removal from power. ${ }^{156}$ The signatories, many of whom had close ties to pro-Israel groups like JINSA or WINEP, and whose ranks included Elliot Abrams, John Bolton, Douglas Feith, William Kristol, Bernard Lewis, Donald Rumsfeld, Richard Perle and Paul Wolfowitz, had little trouble convincing the Clinton Administration to adopt the general goal of ousting Saddam. ${ }^{157}$ But the neoconservatives were unable to sell a war to achieve that objective. Nor were they able to generate much enthusiasm for invading Iraq in the early months of the Bush Administration. ${ }^{158}$ As important as the neoconservatives were for making the Iraq war happen, they needed help to achieve their aim.

That help arrived with 9/11. Specifically, the events of that fateful day led Bush and Cheney to reverse course and become strong proponents of a preventive war to topple Saddam. Neoconservatives in the Lobby-most notably Scooter Libby, Paul Wolfowitz, and Princeton historian Bernard Lewis-played especially critical roles in persuading the President and Vice-President to favor war.

For the neoconservatives, 9/11 was a golden opportunity to make the case for war with Iraq. At a key meeting with Bush at Camp David on September 15, Wolfowitz advocated attacking Iraq before Afghanistan, even though there was no evidence that Saddam was involved in the attacks on the United States and bin Laden was known to be in Afghanistan. ${ }^{159}$ Bush rejected this advice and chose to go after Afghanistan instead, but war with Iraq was now regarded as a serious possibility and the President tasked U.S. military planners on November 21, 2001 with developing concrete plans for an invasion. ${ }^{160}$

Meanwhile, other neoconservatives were at work within the corridors of power. We do not have the full story yet, but scholars like Lewis and Fouad Ajami of John Hopkins University reportedly played key roles in convincing Vice President Cheney to favor the war. ${ }^{161}$ Cheney's views were also heavily influenced by the neoconservatives on his staff, especially Eric Edelman, John Hannah, and chief of staff Libby, one of the most powerful individuals in the Administration. ${ }^{162}$ The Vice President's influence helped convince President Bush by early 2002. With Bush and Cheney on board, the die for war was cast. 
Outside the administration, neoconservative pundits lost no time making the case that invading Iraq was essential to winning the war on terrorism. Their efforts were partly aimed at keeping pressure on Bush and partly intended to overcome opposition to the war inside and outside of the government. On September 20, a group of prominent neoconservatives and their allies published another open letter, telling the President that "even if evidence does not link Iraq directly to the [9/11] attack, any strategy aiming at the eradication of terrorism and its sponsors must include a determined effort to remove Saddam Hussein from power in Iraq." 163 The letter also reminded Bush that, "Israel has been and remains America's staunchest ally against international terrorism." In the October 1 issue of the Weekly Standard, Robert Kagan and William Kristol called for regime change in Iraq immediately after the Taliban was defeated. That same day, Charles Krauthammer argued in the Washington Post that after we were done with Afghanistan, Syria should be next, followed by Iran and Iraq. "The war on terrorism," he argued, "will conclude in Baghdad," when we finish off "the most dangerous terrorist regime in the world." 164

These salvoes were the beginning of an unrelenting public relations campaign to win support for invading Iraq. ${ }^{165}$ A key part of this campaign was the manipulation of intelligence information, so as to make Saddam look like an imminent threat. For example, Libby visited the CIA several times to pressure analysts to find evidence that would make the case for war, and he helped prepare a detailed briefing on the Iraq threat in early 2003 that was pushed on Colin Powell, then preparing his infamous briefing to the U.N. Security Council on the Iraqi threat. ${ }^{166}$ According to Bob Woodward, Powell "was appalled at what he considered overreaching and hyperbole. Libby was drawing only the worst conclusions from fragments and silky threads."167 Although Powell discarded Libby's most outrageous claims, his U.N. presentation was still riddled with errors, as Powell now acknowledges.

The campaign to manipulate intelligence also involved two organizations that were created after 9/11 and reported directly to Undersecretary of Defense Douglas Feith. ${ }^{168}$ The Policy Counterterrorism Evaluation Group was tasked to find links between al Qaeda and Iraq that the intelligence community supposedly missed. Its two key members were Wurmser, a hard core neoconservative, and Michael Maloof, a Lebanese-American who had close ties with Perle. The Office of Special Plans was tasked with finding evidence that could be used to sell war with Iraq. It was headed by Abram Shulsky, a neoconservative with longstanding ties to Wolfowitz, and its ranks included recruits from pro-Israel think tanks. ${ }^{169}$ 
Like virtually all the neoconservatives, Feith is deeply committed to Israel. He also has long-standing ties to the Likud Party. He wrote articles in the 1990s supporting the settlements and arguing that Israel should retain the occupied territories. ${ }^{170}$ More importantly, along with Perle and Wurmser, he wrote the famous "Clean Break" report in June 1996 for the incoming Israeli Prime Minister, Benjamin Netanyahu. ${ }^{171}$ Among other things, it recommended that Netanyahu "focus on removing Saddam Hussein from power in Iraq -- an important Israeli strategic objective in its own right." It also called for Israel to take steps to reorder the entire Middle East. Netanyahu did not implement their advice, but Feith, Perle and Wurmser were soon advocating that the Bush Administration pursue those same goals. This situation prompted $\mathrm{Ha}^{\prime}$ aretz columnist Akiva Eldar to warn that Feith and Perle "are walking a fine line between their loyalty to American governments ... and Israeli interests."172

Wolfowitz is equally committed to Israel. The Forward once described him as "the most hawkishly pro-Israel voice in the Administration," and selected him in 2002 as the first among fifty notables who "have consciously pursued Jewish activism."173 At about the same time, JINSA gave Wolfowitz its Henry M. Jackson Distinguished Service Award for promoting a strong partnership between Israel and the United States, and the Jerusalem Post, describing him as "devoutly pro-Israel," named him "Man of the Year" in 2003. ${ }^{174}$

Finally, a brief word is in order about the neoconservatives' prewar support of Ahmed Chalabi, the unscrupulous Iraqi exile who headed the Iraqi National Congress (INC). They embraced Chalabi because he had worked to establish close ties with Jewish-American groups and had pledged to foster good relations with Israel once he gained power. ${ }^{175}$ This was precisely what pro-Israel proponents of regime change wanted to hear, so they backed Chalabi in return. Journalist Matthew Berger laid out the essence of the bargain in the Jewish Journal: "The INC saw improved relations as a way to tap Jewish influence in Washington and Jerusalem and to drum up increased support for its cause. For their part, the Jewish groups saw an opportunity to pave the way for better relations between Israel and Iraq, if and when the INC is involved in replacing Saddam Hussein's regime."176

Given the neoconservatives' devotion to Israel, their obsession with Iraq, and their influence in the Bush Administration, it is not surprising that many Americans suspected that the war was designed to further Israeli interests. For example, Barry Jacobs of the American Jewish Committee acknowledged in 
March 2005 that the belief that Israel and the neoconservatives conspired to get the United States into a war in Iraq was "pervasive" in the U.S. intelligence community. ${ }^{177}$ Yet few people would say so publicly, and most that did -including Senator Ernest Hollings (D-SC) and Representative James Moran (DVA) -- were condemned for raising the issue. ${ }^{178}$ Michael Kinsley put the point well in late 2002, when he wrote that "the lack of public discussion about the role of Israel ... is the proverbial elephant in the room: Everybody sees it, no one mentions it."179 The reason for this reluctance, he observed, was fear of being labeled an anti-Semite. Even so, there is little doubt that Israel and the Lobby were key factors in shaping the decision for war. Without the Lobby's efforts, the United States would have been far less likely to have gone to war in March 2003.

\section{Dreams of Regional Transformation}

The Iraq war was not supposed to be a costly quagmire. Rather, it was intended as the first step in a larger plan to reorder the Middle East. This ambitious strategy was a dramatic departure from previous U.S. policy, and the Lobby and Israel were critical driving forces behind this shift. This point was made clearly after the Iraq war began in a front-page story in the Wall Street Journal. The headline says it all: "President's Dream: Changing Not Just Regime but a Region: A Pro-U.S., Democratic Area is a Goal that Has Israeli and Neo Conservative Roots." 180

Pro-Israel forces have long been interested in getting the U.S. military more directly involved in the Middle East, so it could help protect Israel. ${ }^{181}$ But they had limited success on this front during the Cold War, because America acted as an "off-shore balancer" in the region. Most U.S. forces designated for the Middle East, like the Rapid Deployment Force, were kept "over the horizon" and out of harm's way. Washington maintained a favorable balance of power by playing local powers off against each other, which is why the Reagan Administration supported Saddam against revolutionary Iran during the Iran-Iraq war (1980-88).

This policy changed after the first Gulf War, when the Clinton Administration adopted a strategy of "dual containment." It called for stationing substantial U.S. forces in the region to contain both Iran and Iraq, instead of using one to check the other. The father of dual containment was none other than Martin Indyk, who first articulated the strategy in May 1993 at the pro-Israel think tank WINEP and then implemented it as Director for Near East and South Asian Affairs at the National Security Council. ${ }^{182}$ 
There was considerable dissatisfaction with dual containment by the mid-1990s, because it made the United States the mortal enemy of two countries who also hated each other, and it forced Washington to bear the burden of containing both of them. ${ }^{183}$ Not surprisingly, the Lobby worked actively in Congress to save dual containment. ${ }^{184}$ Pressed by AIPAC and other pro-Israel forces, Clinton toughened up the policy in the spring of 1995 by imposing an economic embargo on Iran. But AIPAC et al wanted more. The result was the 1996 Iran and Libya Sanctions Act, which imposed sanctions on any foreign companies investing more than $\$ 40$ million to develop petroleum resources in Iran or Libya. As Ze'ev Schiff, the military correspondent for Ha'aretz, noted at the time, "Israel is but a tiny element in the big scheme, but one should not conclude that it cannot influence those within the Beltway." ${ }^{185}$

By the late 1990s, however, the neoconservatives were arguing that dual containment was not enough and that regime change in Iraq was now essential. By toppling Saddam and turning Iraq into a vibrant democracy, they argued, the United States would trigger a far-reaching process of change throughout the Middle East. This line of thinking, of course, was evident in the "Clean Break" study the neoconservatives wrote for Netanyahu. By 2002, when invading Iraq had become a front-burner issue, regional transformation had become an article of faith in neoconservative circles. ${ }^{186}$

Charles Krauthammer describes this grand scheme as the brainchild of Natan Sharansky, the Israeli politician whose writings have impressed President Bush. ${ }^{187}$ But Sharansky was hardly a lone voice in Israel. In fact, Israelis across the political spectrum believed that toppling Saddam would alter the Middle East to Israel's advantage. Aluf Benn reported in Ha'aretz (February 17, 2003), "Senior IDF officers and those close to Prime Minister Ariel Sharon, such as National Security Advisor Ephraim Halevy, paint a rosy picture of the wonderful future Israel can expect after the war. They envision a domino effect, with the fall of Saddam Hussein followed by that of Israel's other enemies ... Along with these leaders will disappear terror and weapons of mass destruction." 188

In short, Israeli leaders, neoconservatives, and the Bush Administration all saw war with Iraq as the first step in an ambitious campaign to remake the Middle East. And in the first flush of victory, they turned their sights on Israel's other regional opponents. 


\section{Gunning for Syria}

Israeli leaders did not push the Bush Administration to put its crosshairs on Syria before March 2003, because they were too busy pushing for war against Iraq. But once Baghdad fell in mid-April, Sharon and his lieutenants began urging Washington to target Damascus. ${ }^{189}$ On April 16, for example, Sharon and Shaul Mofaz, his defense minister, gave high profile interviews in different Israeli newspapers. Sharon, in Yedioth Ahronoth, called for the United States to put "very heavy" pressure on Syria. ${ }^{190}$ Mofaz told Ma'ariv that, "We have a long list of issues that we are thinking of demanding of the Syrians and it is appropriate that it should be done through the Americans." 191 Sharon's national security advisor, Ephraim Halevy, told a WINEP audience that it was now important for the United States to get rough with Syria, and the Washington Post reported that Israel was "fueling the campaign" against Syria by feeding the United States intelligence reports about the actions of Syrian President Bashar Assad. ${ }^{192}$

Prominent members of the Lobby made the same arguments after Baghdad fell. ${ }^{193}$ Wolfowitz declared that "there has got to be regime change in Syria," and Richard Perle told a journalist that "We could deliver a short message, a twoworded message [to other hostile regimes in the Middle East]: 'You're next'." 194 In early April, WINEP released a bipartisan report stating that Syria "should not miss the message that countries that pursue Saddam's reckless, irresponsible and defiant behavior could end up sharing his fate." ${ }^{195}$ On April 15, Yossi Klein Halevi wrote a piece in the Los Angeles Times entitled "Next, Turn the Screws on Syria," while the next day Zev Chafets wrote an article for the New York Daily News entitled "Terror-Friendly Syria Needs a Change, Too." Not to be outdone, Lawrence Kaplan wrote in the New Republic on April 21 that Syrian leader Assad was a serious threat to America. ${ }^{196}$

Back on Capitol Hill, Congressman Eliot Engel (D-NY) had reintroduced the Syria Accountability and Lebanese Sovereignty Restoration Act on April $12 .{ }^{197}$ It threatened sanctions against Syria if it did not withdraw from Lebanon, give up its WMD, and stop supporting terrorism, and it also called for Syria and Lebanon to take concrete steps to make peace with Israel. This legislation was strongly endorsed by the Lobby - especially AIPAC - and "framed," according to the Jewish Telegraph Agency, "by some of Israel's best friends in Congress."198 It had been on the back burner for some time, largely because the Bush Administration had little enthusiasm for it, but the anti-Syrian act passed overwhelmingly (398-4 
in the House; 89-4 in the Senate), and Bush signed it into law on December 12, 2003. ${ }^{199}$

Yet the Bush Administration was still divided about the wisdom of targeting Syria at this time. Although the neoconservatives were eager to pick a fight with Damascus, the CIA and the State Department were opposed. And even after Bush signed the new law, he emphasized that he would go slowly in implementing it. ${ }^{200}$

Bush's ambivalence is understandable. First, the Syrian government had been providing the United States with important intelligence about al Qaeda since 9/11 and had also warned Washington about a planned terrorist attack in the Gulf. ${ }^{201}$ Syria had also given CIA interrogators access to Mohammed Zammar, the alleged recruiter of some of the 9/11 hijackers. Targeting the Assad regime would jeopardize these valuable connections, and thus undermine the larger war on terrorism.

Second, Syria was not on bad terms with Washington before the Iraq war (e.g., it had even voted for U.N. Resolution 1441), and it was no threat to the United States. Playing hardball with Syria would make the United States look like a bully with an insatiable appetite for beating up Arab states. Finally, putting Syria on the American hit list would give Damascus a powerful incentive to cause trouble in Iraq. Even if one wanted to pressure Syria, it made good sense to finish the job in Iraq first.

Yet Congress insisted on putting the screws to Damascus, largely in response to pressure from Israel officials and pro-Israel groups like AIPAC. ${ }^{202}$ If there were no Lobby, there would have been no Syria Accountability Act and U.S. policy toward Damascus would have been more in line with the U.S. national interest.

\section{Putting Iran in the Crosshairs}

Israelis tend to describe every threat in the starkest terms, but Iran is widely seen as their most dangerous enemy because it is the most likely adversary to acquire nuclear weapons. Virtually all Israelis regard an Islamic country in the Middle East with nuclear weapons as an existential threat. As Israeli Defense Minister Binyamin Ben-Eliezer remarked one month before the Iraq war: "Iraq is a problem .... But you should understand, if you ask me, today Iran is more dangerous than Iraq." 203 
Sharon began publicly pushing the United States to confront Iran in November 2002, in a high profile interview in The Times (London). ${ }^{204}$ Describing Iran as the "center of world terror," and bent on acquiring nuclear weapons, he declared that the Bush Administration should put the strong arm on Iran "the day after" it conquered Iraq. In late April 2003, Ha'aretz reported that the Israeli ambassador in Washington was now calling for regime change in Iran. ${ }^{205}$ The overthrow of Saddam, he noted, was "not enough." In his words, America "has to follow through. We still have great threats of that magnitude coming from Syria, coming from Iran."

The neoconservatives also lost no time in making the case for regime change in Tehran. ${ }^{206}$ On May 6, the AEI co-sponsored an all-day conference on Iran with the pro-Israel Foundation for the Defense of Democracies and the Hudson Institute. ${ }^{207}$ The speakers were all strongly pro-Israel, and many called for the United States to replace the Iranian regime with a democracy. As usual, there were a bevy of articles by prominent neoconservatives making the case for going after Iran. For example, William Kristol wrote in the Weekly Standard on May 12 that, "The liberation of Iraq was the first great battle for the future of the Middle East .... But the next great battle -- not, we hope, a military one -- will be for Iran." 208

The Bush Administration has responded to the Lobby's pressure by working overtime to shut down Iran's nuclear program. But Washington has had little success, and Iran seems determined to get a nuclear arsenal. As a result, the Lobby has intensified its pressure on the U.S. government, using all of the strategies in its playbook. ${ }^{209}$ Op-eds and articles now warn of imminent dangers from a nuclear Iran, caution against any appeasement of a "terrorist" regime, and hint darkly of preventive action should diplomacy fail. The Lobby is also pushing Congress to approve the Iran Freedom Support Act, which would expand existing sanctions on Iran. Israeli officials also warn they may take preemptive action should Iran continue down the nuclear road, hints partly intended to keep Washington focused on this issue.

One might argue that Israel and the Lobby have not had much influence on U.S. policy toward Iran, because the United States has its own reasons to keep Iran from going nuclear. This is partly true, but Iran's nuclear ambitions do not pose an existential threat to the United States. If Washington could live with a nuclear Soviet Union, a nuclear China, or even a nuclear North Korea, then it can live with a nuclear Iran. And that is why the Lobby must keep constant pressure on U.S. politicians to confront Tehran. Iran and the United States would hardly be 
allies if the Lobby did not exist, but U.S. policy would be more temperate and preventive war would not be a serious option.

\section{Summary}

It is not surprising that Israel and its American supporters want the United States to deal with any and all threats to Israel's security. If their efforts to shape U.S. policy succeed, then Israel's enemies get weakened or overthrown, Israel gets a free hand with the Palestinians, and the United States does most of the fighting, dying, rebuilding, and paying.

But even if the United States fails to transform the Middle East and finds itself in conflict with an increasingly radicalized Arab and Islamic world, Israel still ends up protected by the world's only superpower. ${ }^{210}$ This is not a perfect outcome from the Lobby's perspective, but it is obviously preferable to Washington distancing itself from Israel, or using its leverage to force Israel to make peace with the Palestinians.

\section{CONCLUSION}

Can the Lobby's power be curtailed? One would like to think so, given the Iraq debacle, the obvious need to rebuild America's image in the Arab and Islamic world, and the recent revelations about AIPAC officials passing U.S. government secrets to Israel. One might also think that Arafat's death and the election of the more moderate Abu Mazen would cause Washington to press vigorously and evenhandedly for a peace agreement. In short, there are ample grounds for U.S. leaders to distance themselves from the Lobby and adopt a Middle East policy more consistent with broader U.S. interests. In particular, using American power to achieve a just peace between Israel and the Palestinians would help advance the broader goals of fighting extremism and promoting democracy in the Middle East.

But that is not going to happen anytime soon. AIPAC and its allies (including Christian Zionists) have no serious opponents in the lobbying world. They know it has become more difficult to make Israel's case today, and they are responding by expanding their activities and staffs. ${ }^{211}$ Moreover, American politicians remain acutely sensitive to campaign contributions and other forms of political pressure and major media outlets are likely to remain sympathetic to Israel no matter what it does. 
This situation is deeply worrisome, because the Lobby's influence causes trouble on several fronts. It increases the terrorist danger that all states face-including America's European allies. By preventing U.S. leaders from pressuring Israel to make peace, the Lobby has also made it impossible to end the Israeli-Palestinian conflict. This situation gives extremists a powerful recruiting tool, increases the pool of potential terrorists and sympathizers, and contributes to Islamic radicalism around the world.

Furthermore, the Lobby's campaign for regime change in Iran and Syria could lead the United States to attack those countries, with potentially disastrous effects. We do not need another Iraq. At a minimum, the Lobby's hostility toward these countries makes it especially difficult for Washington to enlist them against al Qaeda and the Iraqi insurgency, where their help is badly needed.

There is a moral dimension here as well. Thanks to the Lobby, the United States has become the de facto enabler of Israeli expansion in the occupied territories, making it complicit in the crimes perpetrated against the Palestinians. This situation undercuts Washington's efforts to promote democracy abroad and makes it look hypocritical when it presses other states to respect human rights. U.S. efforts to limit nuclear proliferation appear equally hypocritical given its willingness to accept Israel's nuclear arsenal, which encourages Iran and others to seek similar capabilities.

Moreover, the Lobby's campaign to squelch debate about Israel is unhealthy for democracy. Silencing skeptics by organizing blacklists and boycotts-or by suggesting that critics are anti-Semites - violates the principle of open debate upon which democracy depends. The inability of the U.S. Congress to conduct a genuine debate on these vital issues paralyzes the entire process of democratic deliberation. Israel's backers should be free to make their case and to challenge those who disagree with them. But efforts to stifle debate by intimidation must be roundly condemned by those who believe in free speech and open discussion of important public issues.

Finally, the Lobby's influence has been bad for Israel. Its ability to persuade Washington to support an expansionist agenda has discouraged Israel from seizing opportunities -- including a peace treaty with Syria and a prompt and full implementation of the Oslo Accords -- that would have saved Israeli lives and shrunk the ranks of Palestinian extremists. Denying the Palestinians their legitimate political rights certainly has not made Israel more secure, and the long campaign to kill or marginalize a generation of Palestinian leaders has 
empowered extremist groups like Hamas, and reduced the number of Palestinian leaders who would be both willing to accept a fair settlement and able to make it work. This course raises the awful specter of Israel one day occupying the pariah status once reserved for apartheid states like South Africa. Ironically, Israel itself would probably be better off if the Lobby were less powerful and U.S. policy were more evenhanded.

But there is a ray of hope. Although the Lobby remains a powerful force, the adverse effects of its influence are increasingly difficult to hide. Powerful states can maintain flawed policies for quite some time, but reality cannot be ignored forever. What is needed, therefore, is a candid discussion of the Lobby's influence and a more open debate about U.S. interests in this vital region. Israel's well-being is one of those interests, but not its continued occupation of the West Bank or its broader regional agenda. Open debate will expose the limits of the strategic and moral case for one-sided U.S. support and could move the United States to a position more consistent with its own national interest, with the interests of the other states in the region, and with Israel's long-term interests as well. 


\section{ENDNOTES}

${ }^{1}$ Indeed, the mere existence of the Lobby suggests that unconditional support for Israel is not in the American national interest. If it was, one would not need an organized special interest group to bring it about. But because Israel is a strategic and moral liability, it takes relentless political pressure to keep U.S. support intact. As Richard Gephardt, the former House Minority Leader, told the American-Israel Public Affairs Committee (AIPAC), "Without [your] constant support . . . and all your fighting on a daily basis to strengthen that relationship, it would not be." This quote was downloaded from the AIPAC website [http://www.aipac.org/] on January 12, 2004. Also see Michael Kinsley, "J'Accuse, Sort Of," Slate, March 12, 2003.

2 According to the U.S. Agency for International Development's (USAID) "Greenbook," which reports "overseas loans and grants," Israel has received \$140,142,800 (in constant 2003 dollars) from the United States through 2003. Downloaded from the "Greenbook" web site [http://qesdb.cdie.org/gbk/] on November 8, 2005.

3 According to the "Greenbook," Israel received about $\$ 3.7$ billion in direct aid from the United States in 2003. Israel's population according to the International Institute for Strategic Studies [IISS] and the CIA is 6,276,883. IISS, The Military Balance: 2005-2006 (Oxfordshire: Routledge, 2005), p. 192; http://www.cia.gov/cia/publications/factbook/. That averages out to $\$ 589$ per Israeli. If one assumes the same population size and $\$ 3$ billion in total aid, then each Israeli receives $\$ 478$.

4 See http://www.cia.gov/cia/publications/factbook/; World Bank Atlas (Washington, DC: Development Data Group, World Bank, September 2004), pp. 64-65.

${ }^{5}$ For a discussion of the various special deals that Israel receives, see Clyde R. Mark, "Israel: U.S. Foreign Assistance," Issue Brief for Congress (Washington, DC: Congressional Research Service, April 26, 2005).

${ }^{6}$ Avner Cohen, Israel and the Bomb (New York: Columbia University Press, 1999); Seymour M. Hersh, The Samson Option: Israel's Nuclear Arsenal and American Foreign Policy (New York: Random House, 1991).

7 "Report of the Open-Ended Working Group on the Question of Equitable Representation on and Increase in the Membership of the Security Council and Other Matters Related to the Security Council," Annex III, U.N. General Assembly Official Records, 58 ${ }^{\text {th }}$ Session, Supplement No. 47, 2004, pp. 13-14; Donald Neff, "An Updated List of Vetoes Cast by the United States to Shield Israel from Criticism by the U.N. Security Council," Washington Report on Middle East Affairs, May/June 2005; Stephen Zunes, “U.S. Declares Open Season on UN Workers," CommonDreams.org, January 10, 
2003. There were also many resolutions that never came to a vote because Security Council members knew that the United States would veto them. Given the difficulty of criticizing specific Israeli actions in the Security Council, criticism has often come from the U.N. General Assembly, where no state has a veto. In those instances, the United States invariably finds itself on the short end of lopsided votes on the order of say 133-4, where the dissenters include Micronesia and the Marshall Islands as well as Israel and the United States. In response, the Forward reported in November 2003 that the Bush Administration, at the instigation of the American Jewish Committee, was "embarking on the most comprehensive campaign in years to reduce the number of anti-Israel resolutions routinely passed by the United Nations General Assembly." Marc Perelman, "Washington Seeking to Reduce Number of Anti-Israel Votes at U.N.," Forward, November 14, 2003.

${ }^{8}$ Marc Perelman, “International Agency Eyes Israeli Nukes," Forward, September 5, 2003.

${ }^{9}$ William B. Quandt, Peace Process: American Diplomacy and the Arab-Israeli Conflict since 1967, 3rd ed. (Washington, DC: Brookings Institution Press, 2005), chapters 5-7, 10-12.

${ }^{10}$ Nathan Guttman, "U.S. Accused of Pro-Israel Bias at 2000 Camp David," Ha'aretz, April 29, 2005. Also see Aaron D. Miller, "Israel's Lawyer," Washington Post, May 23, 2005; "Lessons of Arab-Israeli Negotiating: Four Negotiators Look Back and Ahead," Transcript of panel discussion, Middle East Institute, April 25, 2005. For general discussions of how the United States consistently favors Israel over the Palestinians, see Noam Chomsky, Fateful Triangle: The United States, Israel and the Palestinians (Cambridge, MA: South End Press, 1999); Kathleen Christison, Perceptions of Palestine: Their Influence on U.S. Middle East Policy (Berkeley, CA: University of California Press, 2001); Naseer H. Aruri, Dishonest Broker: The U.S. Role in Israel and Palestine (Cambridge, MA: South End Press, 2003). It is also worth noting that the British favored the Zionists over the Palestinians during the period of the British Mandate (1919-1948). See Tom Segev, One Palestine, Complete: Jews and Arabs under the British Mandate (New York: Henry Holt, 2000).

${ }^{11}$ Downloaded from AIPAC's website [http://aipac.org/documents/unitedefforts.html] on January 12, 2006.

12 See, for example, Warren Bass, Support Any Friend: Kennedy's Middle East and the Making of the US-Israel Alliance (NY: Oxford University Press, 2003); A.F.K. Organski, The $\$ 36$ Billion Bargain: Strategy and Politics in U.S. Assistance to Israel (New York: Columbia University Press, 1990); Steven L. Spiegel, "Israel as a Strategic Asset," Commentary, June 1983, pp. 51- 55; Idem, The Other Arab-Israeli Conflict: Making America's Middle East Policy, from Truman to Reagan (Chicago: University of Chicago Press, 1985). 
${ }^{13}$ This point was not lost on Moshe Dayan, who, remembering a talk he had with Henry Kissinger at the time of the October 1973 War, noted that "though I happened to remark that the United States was the only country that was ready to stand by us, my silent reflection was that the United States would really rather support the Arabs." Moshe Dayan, Moshe Dayan: Story of My Life (NY: William Morrow, 1976), pp. 521-513. Also see Zach Levey, "The United States' Skyhawk Sale to Israel, 1966: Strategic Exigencies of an Arms Deal," Diplomatic History, Vol. 28, No. 2 (April 2004), pp.255-276.

${ }^{14}$ Bernard Lewis wrote in 1992, "Whatever value Israel might have had as a strategic asset during the Cold War, that value obviously ended when the Cold War itself came to a close. The change was clearly manifested in the Gulf War last year, when what the United States most desired from Israel was to keep out of the conflict -- to be silent, inactive and, as far as possible, invisible .... Israel was not an asset, but an irrelevance -some even said a nuisance. Some of the things that the Israeli government later said and did were unlikely to change this perception." "Rethinking the Middle East," Foreign Affairs, Vol. 71, No. 4, (Fall 1992), pp. 110-111.

${ }^{15}$ According to Middle East expert Shibley Telhami, "No other issue resonates with the public in the Arab world, and many other parts of the Muslim world, more deeply than Palestine. No other issue shapes the regional perceptions of America more fundamentally than the issue of Palestine." The Stakes: America and the Middle East (Boulder, CO: Westview Press, 2002), p. 96. Lakhdar Brahimi, the former U.N. special envoy to Iraq, who the Bush Administration enlisted to help form an interim Iraqi government in June 2004, said that Israeli policy toward the Palestinians is "the great poison in the region," and that "in the region, and beyond" people recognized the "injustice of this policy and the equally unjust support of the United States for this policy." See Warren Hoge, “U.N. Moves to Disassociate Itself from Remarks by Envoy to Iraq," New York Times, April 23, 2004; “Brahimi's Israel Comments Draw Annan, Israel Ire," Ha'aretz, April 24, 2004. Also see the comments of Egyptian President Hosni Mubarak in "Mubarak: Arab Hatred of America Growing," Washington Post, April 20, 2004. Finally, see Ami Eden, “9/11 Commission Finds Anger at Israel Fueling Islamic Terrorism Wave," Forward, July 30, 2004.

${ }^{16}$ National Commission on Terrorist Attacks against the United States, "Outline of the 9/11 Plot," Staff Statement No. 16, June 16, 2004. Also see Nathan Guttman, "Al-Qaida Planned Attacks during PM's Visit to White House," Ha'aretz, June 17, 2004; and Marc Perelman, "Bin Laden Aimed to Link Plot to Israel," Forward, June 25, 2004. Pro-Israel supporters often argue that bin Laden only became interested in the Israel-Palestinian conflict after 9/11, and only because he thought that it was good for recruiting purposes. Thus, there is virtually no connection between what happened on 9/11 and U.S. support for Israel. See Andrea Levin, “Don't Scapegoat Israel,” Boston Globe, October 6, 2001; Norman Podhoretz, "Israel Isn't the Issue," Wall Street Journal, September 20, 2001. Note 
that both of these pieces were published right after the Twin Towers fell. However, we now have a substantial number of bin Laden's writings and talks from the 1980s and 1990s, and it is clear that he cared deeply about matters relating to Jerusalem and the Palestinians long before 9/11. See, for example, "Jihad against Jews and Crusaders," World Islamic Front Statement, February 23, 1998; Transcript of Osama bin Laden's March 20, 1997 interview with Peter Arnett of CNN (first broadcast on May 10, 1997). Also "New Osama bin Laden Video Contains Anti-Israel and Anti-American Statements," downloaded from the Anti-Defamation League (ADL) website [http://www.adl.org/terrorism_america/bin_1_print.asp] on March 8, 2004.

${ }_{17}$ Changing Minds, Winning Peace: A New Strategic Direction for U.S. Public Diplomacy in the Arab and Muslim World, Report of the Advisory Group on Public Diplomacy for the Arab and Muslim World, Submitted to the Committee on Appropriations, U.S. House of Representatives, October 1, 2003, p. 18. Also see The Pew Global Attitudes Project, Views of a Changing World 2003: War With Iraq Further Divides Global Publics (Washington, DC: The Pew Research Center for the People and the Press, June 3, 2003); Report of the Defense Science Board Task Force on Strategic Communication (Washington, DC: Office of the Undersecretary of Defense for Acquisition, Technology, and Logistics, September 2004); Shibley Telhami, "Arab Public Opinion: A Survey in Six Countries," San Jose Mercury, March 16, 2003; John Zogby, The Ten Nation Impressions of America Poll (Utica, NY: Zogby International, April 11, 2002); Idem, Impressions of America 2004: How Arabs View America, How Arabs Learn about America (Six Nation Survey), (Utica, NY: Zogby International, 2004).

${ }^{18}$ See The Pew Global Attitudes Project, America Admired, Yet Its New Vulnerability Seen As Good Thing, Say Opinion Leaders (Washington, DC: The Pew Research Center for the People and the Press, December 19, 2001); Pew Global Attitudes Project, Views of a Changing World 2003, p. 5.

${ }^{19}$ For a copy of the letter, see "Doomed to Failure in the Middle East," The Guardian, April 27, 2004. Also see Nicholas Blanford, "US Moves Inflame Arab Moderates," The Christian Science Monitor, April 26, 2004; Rupert Cornwell, "Allies Warn Bush that Stability in Iraq Demands Arab-Israeli Deal," The Independent, June 10, 2004; Glenn Kessler and Robin Wright, "Arabs and Europeans Question 'Greater Middle East' Plan," Washington Post, February 22, 2004; Paul Richter, “U.S. Has Fresh Hope for Mideast,” Los Angeles Times, November 7, 2004; Robin Wright and Glenn Kessler, “U.S. Goals for Middle East Falter," Washington Post, April 21, 2004. Even some Israelis understand that "the continuation of this conflict, including the Israeli occupation, will most certainly lead to new waves of terror; international terrorism, which the Americans fear so much, will spread." Ze'ev Schiff, "Fitting into America's Strategy," Ha'aretz, August 1, 2003. It is also worth noting that some 50 retired American diplomats wrote a letter in May 2004 to President Bush similar to the letter that the British diplomats sent to Tony Blair. A 
copy of the American letter was published in The New York Review of Books, November $18,2004$.

${ }^{20}$ Consider, for example, the controversy that erupted in 2005 over Israel's decision to expand its settlements in the West Bank. See Aluf Benn, "We Can't Expect Explicit U.S. Okay to Build in Settlements," Ha'aretz, March 28, 2005; Akiva Eldar, "Bush: End Expansion of Settlements," Ha'aretz, May 27, 2005; "Bush Warns Israel over West Bank," BBC News Online, April 11, 2005; Donald Macintyre, "Sharon Vows to Defy Bush over Expansion of Israeli Settlements," Independent, April 22, 2005; "Sharon Brushes Off Warning from Bush," MSNBC.com, April 12, 2005; Amy Teibel, "U.S. to Israel: Stop Expanding Settlements," Washington Post, June 26, 2005; Ze'ev Schiff, "U.S.: Israel Shirking Its Promises on Settlement Boundaries," Ha'aretz, March 15, 2005. Regarding targeted assassinations Prime Minister Sharon promised Secretary of State Colin Powell in May 2003 that Israel would refrain from killing Palestinian leaders unless there was a "ticking bomb" (an imminent attack). Ze'ev Schiff, "Focus/Americans Fear Abu Mazen Is Further Weakened," Ha'aretz, June 12, 2003. But one month later, after Bush made a high-profile visit to the Middle East and the prospects for negotiations between the warring parties looked promising, Sharon launched seven assassination missions in five days, none involving a "ticking bomb." Bradley Burston, "Background: Has Sharon's Hamas Hitlist Converted Bush?" Ha'aretz, June 17, 2003. Also see Uri Avnery, "Avoiding a Road Map to the Abyss," Arab News (online), August 26, 2003; Glenn Kessler, "White House Backs Latest Israeli Attacks," Washington Post, June 13, 2003; Laura King, "Sharon Lauds Hebron Killing," Los Angeles Times, June 23, 2003; Gideon Levy, “Who Violated the Hudna?" Tikkun (online), August 17, 2003. In March 2004, the IDF killed Hamas spiritual leader Sheik Yassin, even though he was not an imminent threat, and even though his death damaged America's position in the Middle East. Georgie Anne Geyer, "Ariel Sharon Complicates U.S. Mission," Chicago Tribune, March 26, 2004; H.D.S. Greenway, "Assassination Fallout Bodes Ill for US," Boston Globe, March 26, 2004; Tony Karon, "How Israel's Hamas Killing Affects the U.S.," Time, March 23, 2004; David R. Sands, "Israel's Killing of Yassin Puts US in Line of Fire," Washington Times, March 23, 2004. As Jim Hoagland said in the wake of Yassin's killing, "With the possible exception of Charles de Gaulle, no friendly foreign leader has complicated modern American diplomacy more consistently or gravely than Ariel Sharon. He pursues Israel's interests with a warrior's tenacity and directness that takes away the breath, and the options, of everyone else." See "Consequences for Sharon -- and the U.S.," Chicago Tribune, March 26, 2004.

${ }^{21}$ Quoted in Duncan L. Clarke, "Israel's Unauthorized Arms Transfers," Foreign Policy, No. 99 (Summer 1995), p. 94. This article provides an excellent discussion of the problem. There was a bitter controversy in 2004-2005 between the United States and Israel over Israeli arms sales to China. See Aluf Benn and Amnon Barzilai, "Pentagon Official Wants Yaron Fired," Ha'aretz, December 16, 2004; Aluf Benn, “U.S. Keeps Israel 
Out of New Fighter-Jet Development Program," Ha'aretz, October 12, 2005; Nina Gilbert, "Yaron Won't Give Info on Arms Sales to China," Jerusalem Post, December 30, 2004;

"Israeli, U.S. Talks on Weapons Deals with China End without Result," Ha'aretz, June 29, 2005; Marc Perelman, "Spat Over Sales of Weapons Chilling Ties between Jerusalem and Beijing," Forward, December 23, 2004; Marc Perelman, "China Crisis Straining U.S.-Israel Ties," Forward, August 5, 2005; Marc Perelman, "Israel Miffed over Lingering China Flap," Forward, October 7, 2005; Ze'ev Schiff, "U.S.-Israel Crisis Deepens over Defense Exports to China," Ha'aretz, July 27, 2005.

${ }^{22}$ Quoted in Duncan L. Clarke, "Israel's Economic Espionage in the United States," Journal of Palestine Studies, Vol. 27, No. 4 (Summer 1998), p. 21. Also see Bob Drogin and Greg Miller, "Israel Has Long Spied on U.S. Say Officials," Los Angeles Times, September 3, 2004; "FBI Says Israel a Major Player in Industrial Espionage," Jewish Bulletin, January 16, 1998; Clyde R. Mark, “Israeli-United States Relations," Issue Brief for Congress (Washington, DC: Congressional Research Service, November 9, 2004), pp. 14-15; Joshua Mitnick, “U.S. Accuses Officials of Spying,” Washington Times, December 16, 2004.

${ }^{23}$ On the Pollard affair, see Hersh, Samson Option, pp. 285-305; Idem, "The Traitor: Why Pollard Should Never Be Released," New Yorker, Vol. 74, issue 42 (January 18, 1999), pp. 26-33. There are a huge number of articles on the internet dealing with the Franklin Affair. For a good overview of the case, see Jeffrey Goldberg, "Real Insiders: A Pro-Israel Lobby and an F.B.I. Sting," New Yorker, Vol. 81, issue 19 (July 4, 2005), pp. 34-40.

24 Trevor N. Dupuy, Elusive Victory: The Arab-Israeli Wars, 1947-1974 (New York: Harper and Row, 1978), pp. 3-19, 121-125, 146-147, 212-214, 231-244, 333-340, 388-390, 597-605, 623-633; Simha Flapan, The Birth of Israel: Myths and Realities (New York: Pantheon Books, 1987), pp. 189-199; Rashid Khalidi, “The Palestinians and 1948: The Underlying Causes of Failure," in Eugene L. Rogan and Avi Shlaim, eds., The War for Palestine: Rewriting the History of 1948 (NY: Cambridge University Press, 2001), pp. 12-36; Haim Levenberg, Military Preparations of the Arab Community in Palestine, 1945-1948 (London: Frank Cass, 1993); Benny Morris, The Birth of the Palestinian Refugee Problem Revisited (New York: Cambridge University Press, 2004), chapters 1,3. Idem, Righteous Victims: A History of the Zionist-Arab Conflict, 1881-1999 (New York: Alfred Knopf, 1999), pp. 187189, 191-196, 217-223, 235-236, 241-242, 286-291, 311-313, 393-395; Martin Van Creveld, The Sword and the Olive: A Critical History of the Israeli Defense Forces (NY: Public Affairs, 1998), pp. 77-82, 137-138, 179-182.

${ }^{25}$ Amos Harel, "Israel Maintains Its Strategic Advantage, Says Jaffee Center," Ha'aretz, November 23, 2005. Also see, Uri Bar-Joseph, "The Paradox of Israeli Power," Survival, Vol. 46, No. 4 (Winter 2004-05), pp. 137-156; Martin Van Creveld, “Opportunity Beckons," Jerusalem Post, May 15, 2003. 
${ }^{26}$ For three instructive pieces on this matter from the Israeli press, see Amiram Barkat, "Majority of Israelis Are Opposed to Intermarriage, Survey Finds," Ha'aretz, September 15, 2003; Nicky Blackburn, "Better a Jew," Ha'aretz, April 21, 2004; Lily Galili, “Hitting Below the Belt," Ha'aretz, August 8, 2004.

${ }^{27}$ See "The Official Summation of the Or Commission Report," published in Ha'aretz, September 2, 2003. For evidence of how hostile many Israelis were to the report's findings and recommendations, see "No Avoiding the Commission Recommendations," Ha'aretz, September 4, 2003; Molly Moore, "Israeli Report Is Welcomed, Dismissed," Washington Post, September 3, 2003. Also see Bernard Avishai, "Saving Israel from Itself: A Secular Future for the Jewish State," Harper's Magazine, January 2005. It is also worth noting that the Israel Democracy Institute reported in May 2003 that: 53 percent of Israeli Jews "are against full equality for the Arabs"; 77 percent of Israeli Jews believe that "there should be a Jewish majority on crucial political decisions"; only 31 percent "support having Arab political parties in the government"; 57 percent "think that the Arabs should be encouraged to emigrate." See "The Democracy Index: Major Findings 2003." Imagine the outcry that would occur if a majority of white Americans declared that blacks, Hispanics, and Asians "should be encouraged" to leave the United States. For more recent surveys, which show little change in Israeli attitudes, see Yulie Khromchenko, "Survey: Most Jewish Israelis Support Transfer of Arabs," Ha'aretz, June 22, 2004; Yoav Stern, “Poll: Most Israeli Jews Say Israeli Arabs Should Emigrate," Ha'aretz, April 4, 2005.

${ }^{28}$ Quoted in Justin Huggler, "Israel Imposes 'Racist' Marriage Law," Guardian, August 1, 2003. Also see James Bennet, "Israel Blocks Palestinians from Marrying into Residency," New York Times, July 31, 2003; “Racist Legislation," Ha'aretz editorial, July, 19, 2004; "Racist Legislation," Ha'aretz editorial, January 18, 2005. Even the Anti-Defamation League (ADL) criticized the legislation, albeit mildly. Nathan Guttman, Yair Ettinger, Sharon Sadeh, "ADL Criticizes Law Denying Citizenship to Palestinians," Ha'aretz, August 5, 2003.

${ }^{29}$ The first wave of European Jews to come to Palestine is known as the First Aliyah, and it covers the years from 1882 to 1903. There were slightly more than 15,000 Jews in Palestine in 1882. Justin McCarthy, The Population of Palestine: Population History and Statistics of the Late Ottoman Period and the Mandate (NY: Columbia University Press, 1990), p.11, which has excellent data for the years from 1850 to 1915. Also see Mark Tessler, A History of the Israeli-Palestinian Conflict (Bloomington, IN: Indiana University Press, 1994), p. 124.

30 The total population of Palestine in 1893 was roughly 530,000, of whom about 19,000 were Jewish (3.6 percent). Arabs comprised the vast majority of the remaining population. McCarthy, Population of Palestine, p. 11. 
${ }^{31}$ Flapan, Birth of Israel, p. 44; Morris, Righteous Victims, p. 186.

32 Flapan, Birth of Israel, p 22. Similarly, Ben-Gurion told his son, "I am certain we will be able to settle in all the other parts of the country, whether through agreement and mutual agreement with our Arab neighbors or in another way." He went on to say, "Erect a Jewish State at once, even if it is not in the whole of the land. The rest will come in the course of time. It must come." Avi Shlaim, The Iron Wall: Israel and the Arab World (NY: Norton, 2000), p. 21. Also see Flapan, Birth of Israel, pp. 13-53; Nur Masalah, Expulsion of the Palestinians: The Concept of Transfer in Zionist Political Thought, 1882-1948 (Washington, DC: Institute for Palestine Studies, 1992), chapter 2; Morris, Righteous Victims, pp. 138-139; Avi Shlaim, The Politics of Partition: King Abdullah, the Zionists, and Palestine, 1921-1951 (NY: Oxford University Press, 1999).

${ }^{33}$ Masalah, Expulsion of the Palestinians, p. 128. Also see Morris, Righteous Victims, pp. $140,142,168-169$.

${ }^{34}$ Benny Morris, "A New Exodus for the Middle East?" Guardian, October 3, 2002. On the pervasiveness of transfer thinking among Zionists before Israel was established in 1948, see Masalha, Expulsion of the Palestinians; Morris, "Revisiting the Palestinian Exodus of 1948," in Rogan and Shlaim, War for Palestine, pp. 39-48; Morris, Birth Revisited, chapter 2; Ari Shavit, "Survival of the Fittest," Ha'aretz, January 9, 2004.

${ }^{35}$ Morris, Birth Revisited, provides a detailed account of this event. Also see Meron Benvenisti, Sacred Landscape: The Buried History of the Holy Land since 1948, trans. Maxine Kaufman-Lacusta (Berkeley, CA: University of California Press, 2000), chapters 3-4. The only remaining debate of real significance regarding the expulsion of the Palestinians from their homeland is whether it was "born of war," as Morris argues, or by design, as Norman Finkelstein argues in Image and Reality of the Israel-Palestine Conflict (London: Verso, 1995), chapter 3.

${ }^{36}$ Erskine Childers, “The Other Exodus," Spectator, May 12, 1961; Flapan, Birth of Israel, pp. 81-118; Walid Khalidi, "Why Did the Palestinians Leave Revisited," Journal of Palestine Studies, Vol. 34, No. 2 (Winter 2005), pp. 42-54; Idem, “The Fall of Haifa," Middle East Forum, Vol. 35, No. 10 (December, 1959), pp. 22-32; Morris, Birth Revisited.

${ }^{37}$ Nahum Goldmann, The Jewish Paradox, trans. Steve Cox (NY: Grosset and Dunlap, 1978), p. 99. Ze'ev Jabotinsky, the founding father of the Israeli right, made essentially the same point when he wrote, "Colonization is self-explanatory and what it implies is fully understood by every sensible Jew and Arab. There can only be one purpose in colonization. For the country's Arabs that purpose is essentially unacceptable. This is a natural reaction and nothing will change it." Quoted in Ian Lustick, "To Build and To 
Be Built By: Israel and the Hidden Logic of the Iron Wall," Israel Studies, Vol. 1, No. 1 (Spring 1996), p. 200.

${ }^{38}$ See Geoffrey Aronson, Israel, Palestinians, and the Intifada: Creating Facts on the West Bank (London: Kegan Paul International, 1990); Amnon Barzilai, “A Brief History of the Missed Opportunity," Ha'aretz, June 5, 2002; Idem, "Some Saw the Refugees as the Key to Peace," Ha'aretz, June 11, 2002; Moshe Behar, "The Peace Process and Israeli Domestic Politics in the 1990s," Socialism and Democracy, Current Issue Number 32, Vol. 16, No. 2 (Summer-Fall 2002), pp. 34-47; Adam Hanieh and Catherine Cook, "A Road Map to the Oslo Cul-de-Sac," Middle East Report Online, May 15, 2003; "Israel's Interests Take Primacy: An Interview with Dore Gold," in bitterlemons.org, "What Constitutes a Viable Palestinian State?" March 15, 2004, Edition 10; Nur Masalha, Imperial Israel and the Palestinians: The Politics of Expansion (London: Pluto Press, 2000); Sara Roy, "Erasing the 'Optics' of Gaza,” The Daily Star On Line, February 14, 2004; “36 Years, and Still Counting," Ha'aretz, September 26, 2003.

${ }^{39}$ Rahid Khalidi, Palestinian Identity: The Construction of Modern National Consciousness (NY: Columbia University Press, 1997), p. 147. Meir also said, “It was not as though there was a Palestinian people in Palestine considering itself as a Palestinian people and we came and threw them out and took their country away from them. They did not exist." Masalha, Imperial Israel, p. 47. Rabin said in 1995, two years after signing the Oslo accords, "I seek peaceful coexistence between Israel as a Jewish state, not all over the land of Israel, or most of it; its capital, the united Jerusalem; its security border with Jordan rebuilt; next to it, a Palestinian entity, less than a state, that runs the life of Palestinians .... This is my goal, not to return to the pre-Six Day War lines but to create two entities, a separation between Israel and the Palestinians who reside in the West Bank and the Gaza Strip." Hanieh and Cook, "Road Map." Also see Akiva Eldar, "On the Same Page, Ten Years On," Ha'aretz, November 5, 2005; David Grossman, "The Night Our Hope for Peace Died," Guardian, November 4, 2005; Michael Jansen, "A Practice that Prevents the Emergence of a Palestinian State," Jordan Times, November 10, 2005. It is worth noting that in the spring of 1998, Israel and its American supporters sharply criticized First Lady Hillary Clinton for saying that, "It would be in the longterm interests of peace in the Middle East for there to be a state of Palestine, a functioning modern state that is on the same footing as other states." Tom Rhodes and Christopher Walker, "Congress Tells Israel to Reject Clinton's Pullout Plan," New York Times, May 8, 1998; James Bennet, “Aides Disavow Mrs. Clinton on Mideast," New York Times, May 8, 1998.

${ }^{40}$ Charles Enderlein, Shattered Dreams: The Failure of the Peace Process in the Middle East, 1995-2002, trans. Susan Fairfield (NY: Other Press, 2003), pp. 201, 207-208; Jeremy Pressman, "Visions in Collision: What Happened at Camp David and Taba? International Security, Vol. 28, No. 2 (Fall 2003), p. 17; Deborah Sontag, “Quest for Mideast Peace: 
How and Why It Failed," New York Times, July 26, 2001; Clayton E. Swisher, The Truth about Camp David: The Untold Story about the Collapse of the Peace Process (NY: Nation Books, 2004), pp. 284, 318, 325. Barak himself said after Camp David that "the Palestinians were promised a continuous piece of sovereign territory except for a razorthin Israeli wedge running from Jerusalem through from Maale Adumim to the Jordan River," which effectively would have been under Israel's control. Benny Morris, "Camp David and After: An Exchange (1. An Interview with Ehud Barak)", New York Review of Books, Vol. 49, No. 10 (June 13, 2002), p. 44. Also see the map Israeli negotiators presented to the Palestinians at Camp David, a copy of which can be found in Roane Carey, ed., The New Intifada: Resisting Israel's Apartheid (London: Verso, 2001), p. 36.

${ }^{41}$ See Alan Dershowitz, The Case for Israel (Hoboken, NJ: John Wiley \& Sons, 2003). For a telling critique of Dershowitz's book, see Norman G. Finkelstein, Beyond Chutzpah: On the Misuse of Anti-Semitism and the Abuse of History (Berkeley: University of California Press, 2005). Also see “Dershowitz v. Desch," American Conservative, January 16, 2005.

${ }^{42}$ Morris, Righteous Victims, chapters 2-5.

${ }^{43}$ Morris, Birth Revisited. It should be noted that many Israeli documents concerning the events of 1948 remain classified; Morris expects "that with respect to both expulsions and atrocities, we can expect additional revelations as the years pass and more Israeli records become available." Morris, "Revisiting the Palestinian Exodus," in Rogan and Shlaim, War for Palestine, p. 49. In fact, he maintains that the reported cases of rape he knows about are "just the tip of the iceberg." See Shavit, "Survival of the Fittest."

${ }^{44}$ Benny Morris, Israel's Border Wars, 1949-1956 (New York: Oxford University Press, 1997), p. 432. Also see ibid., pp. 126-153, 178-184. For evidence of similar behavior after the 1967 War, see Uri Avnery, “Crying Wolf?" CounterPunch, March 15, 2003; Ami Kronfeld, "Avnery on Ethnic Cleansing and a Personal Note," in Jewish Voice for Peace, Jewish Peace News, March 17, 2003; Katherine M. Metres, "As Evidence Mounts, Toll of Israeli Prisoner of War Massacres Grows," Washington Report on Middle East Affairs, February/March 1996, pp. 17, 104-105.

${ }^{45}$ During his negotiations with the British and French governments over the launching of the 1956 war, Ben-Gurion proposed a grand plan for reordering the region that would have divided Jordan between Israel and Iraq, transferred all of Lebanon south of the Litani River to Israel, and given Israel portions of the Sinai as well. On Israel's policies in the 1950s, see Morris, Israel's Border Wars; Morris, Righteous Victims, chapter 6, especially pp. 289-290; Shlaim, Iron Wall, chapters 3-4, especially pp.184-185; Kennett Love, Suez: the Twice Fought War (New York: McGraw-Hill, 1969), pp. 589-638; Michael Brecher, Decisions in Israel's Foreign Policy (New Haven: Yale University Press, 1975), pp. 282-283. 
${ }^{46}$ Gabby Bron, "Egyptian POWs Ordered to Dig Graves, Then Shot by Israeli Army," Yedioth Ahronoth, August 17, 1995; Ronal Fisher, "Mass Murder in the 1956 Sinai War," Ma'ariv, August 8, 1995 [Copies of these two pieces can be found in Journal of Palestine Studies, Vol. 25, No. 3 (Spring 1996), pp. 148-155]; Galal Bana, “Egypt: We Will Turn to the International War Crimes Tribunal in the Hague if Israel Will Not Compensate Murdered Prisoners of War," Ha'aretz, July 24, 2002; Zehavat, Friedman, "Personal Reminiscence: Remembering Ami Kronfeld," in Jewish Voice for Peace, Jewish Peace News, September 25, 2005; Metres, "As Evidence Mounts."

${ }^{47}$ Avnery, "Crying Wolf"; Robert Blecher, "Living on the Edge: The Threat of 'Transfer' in Israel and Palestine," MERIP, Middle East Report 225, Winter 2002; Baruch Kimmerling, Politicide: Ariel Sharon's War against the Palestinians (London: Verso, 2003), p. 28. Also see Chomsky, Fateful Triangle, p. 97; Morris, Righteous Victims, pp. 328-329; Tanya Reinhart, Israel/Palestine: How to End the War of 1948 (NY: Seven Stories Press, 2002), p. 8. Morris reports (p. 329) that 120,000 Palestinians applied to return to their homes right after the 1967 War, but Israel allowed only about 17,000 to come back. Amnesty International estimated in mid-2003 that in the years since Israel had acquired the West Bank and the Gaza Strip, it had destroyed more than 10,000 Palestinian homes in those areas. Danny Rubinstein, "Roads, Fences and Outposts Maintain Control in the Territories," Ha'aretz, August 12, 2003.

48 "Report of the Commission of Inquiry into the Events at the Refugee Camps in Beirut," February 7, 1983. The report is commonly called “The Kahan Commission Report" after its chairman, Yitzhak Kahan.

${ }^{49}$ Swedish Save the Children, "The Status of Palestinian Children during the Uprising in the Occupied Territories," Excerpted Summary Material, Jerusalem, 1990, in Journal of Palestine Studies, Vol. 19, No. 4 (Summer 1990), pp. 136-146. Also see Joshua Brilliant, “Officer Tells Court Villagers Were Bound, Gagged and Beaten. 'Not Guilty' Plea at 'Break Bones' Trial," Jerusalem Post, March 30, 1990; Joshua Brilliant, “'Rabin Ordered Beatings', Meir Tells Military Court," Jerusalem Post, June 22, 1990; Jackson Diehl, "Rights Group Accuses Israel of Violence Against Children in Palestinian Uprising," Washington Post, May 17, 1990; James A. Graff, "Crippling a People: Palestinian Children and Israeli State Violence," Alif, No. 13 (1993), pp. 46-63; Ronald R. Stockton, "Intifada Deaths," Journal of Palestine Studies, Vol. 19, No. 4 (Summer 1990), pp. 86-95. Ehud Barak, the IDF's Deputy Chief of Staff during the First Intifada, said at the time, "We do not want children to be shot under any circumstances .... When you see a child you don't shoot." Nevertheless, the Swedish Save the Children report estimated that 6,500 to 8,000 children were wounded by gunfire during the first two years of the Intifada. Researchers investigated 66 of the 106 recorded cases of "child gunshot deaths." They concluded that: almost all of them "were hit by directed -- not random or ricochet -- 
gunfire"; nearly twenty percent suffered multiple gunshot wounds; twelve percent were shot from behind; fifteen percent of the children were ten years of age or younger; "most children were not participating in a stone-throwing demonstration when shot dead"; and "nearly one-fifth of the children were shot dead while at home or within ten meters of their homes."

50 "Unbridled Force," Ha'aretz editorial, March 16, 2003. For other evidence, see Jonathan Cook, "Impunity on Both Sides of the Green Line," MERIP, Middle East Report Online, November 23, 2005; "When Everything Is Permissible," Ha'aretz editorial, June 6, 2005; "It Can Happen Here," Ha'aretz editorial, November 22, 2004; Chris McGreal, "Snipers with Children in Their Sights," Guardian, June 28, 2005; Idem, "Israel Shocked by Image of Soldiers Forcing Violinist to Play at Roadblock," Guardian, November 29, 2004; Greg Myre, "Former Israeli Soldiers Tell of Harassment of Palestinians," New York Times, June 24, 2004; Reuven Pedatzur, "The Message to the Soldiers Was Clear," Ha'aretz, December 13, 2004; Conal Urquhart, "Israeli Soldiers Tell of Indiscriminate Killings by Army and A Culture of Impunity," Guardian, September 6, 2005.

${ }^{51}$ See Swisher, Truth about Camp David, p. 387.

52 According to B'tselem, between September 29, 2000, and December 31, 2005, 3,386 Palestinians were killed by the Israelis, of whom 676 were children. Of those 3,386 deaths, 1,185 were bystanders, 1,008 were killed while fighting the Israelis, and the circumstances of 563 deaths are unknown. During the same period, 992 Israelis were killed by the Palestinians, 118 of whom were children. Of those 992 deaths, 683 were civilians and 309 belonged to Israeli security forces. B'tselem press release, January 4 , 2006.

${ }^{53}$ Nathan Guttman, "'It's a Terrible Thing, Living with the Knowledge that You Crushed Our Daughter'," Ha'aretz, April 30, 2004; Adam Shapiro, "Remembering Rachel Shapiro," Nation, March 18, 2004; Tsahar Rotem, "British Peace Activist Shot by IDF Troops in Gaza Strip," Ha'aretz, April 11, 2003.

${ }^{54}$ Molly Moore, "Ex-Security Chiefs Turn on Sharon," Washington Post, November 15, 2003; "Ex-Shin Bet Heads Warn of 'Catastrophe' without Peace Deal," Ha'aretz, November 15, 2003. These comments were based on an interview in the Israeli newspaper Yedioth Ahronoth on November 14, 2003. For a copy of that interview, see "We Are Seriously Concerned about the Fate of the State of Israel," The Alternative Information Center, December 1, 2003.

${ }^{55}$ Bill Maxwell, “U.S. Should Reconsider Aid to Israel,” St. Petersburg Times, December 16, 2001. 
${ }^{56}$ See J. Bowyer Bell, Terror Out of Zion: The Fight for Israeli Independence ( New Brunswick, NJ: Transaction Publishers, 1996); Joseph Heller, The Stern Gang: Ideology, Politics and Terror, 1940-1949 (London: Frank Cass, 1995); Bruce Hoffmann, The Failure of British Military Strategy within Palestine, 1939-1947 (Israel: Bar-Ilan University, 1983); Morris, Righteous Victims, pp. 173-180; Segev, One Palestine, pp. 468-486. According to Haim Levenberg, 210 of the 429 casualties from Jewish terrorism in Palestine during 1946 were civilians. The other 219 were police and soldiers. Levenberg, Military Preparations, p. 72. Furthermore, it was Jewish terrorists from the infamous Irgun who in late 1937 introduced the practice of placing bombs in buses and large crowds. Benny Morris speculates that, "The Arabs may well have learned the value of terrorist bombings from the Jews." Righteous Victims, pp. 147, 201. Also see Lenni Brenner, The Iron Wall: Zionist Revisionism from Jabotinsky to Shamir (London: Zed Books, 1984), p. 100; Yehoshua Porath, The Palestinian Arab National Movement: from Riots to Rebellion, Vol. II, 1929-1939 (London: Frank Cass, 1977), p. 238. Finally, Morris notes that during the 1948 war the main Jewish terrorist groups "knowingly planted bombs in bus stops with the aim of killing non-combatants, including women and children." Birth Revisited, p. 80.

${ }^{57}$ Bell, Terror Out of Zion, pp. 336-340.

${ }^{58}$ Quoted in Chomsky, Fateful Triangle, pp. 485-486. Israeli Prime Minister Levi Eshkol used to call Menachem Begin "the terrorist." Barzilai, "Brief History." On Shamir, see Avishai Margalit, "The Violent Life of Yitzhak Shamir," New York Review of Books, May 14, 1992, pp. 18-24.

${ }^{59}$ Moreover, Israel's claim to a morally superior status is undermined by some of its other policies. Israel once cultivated close ties with apartheid-era South Africa and aided the white minority government's nuclear weapons program. Peter Liberman, "Israel and the South African Bomb," The Nonproliferation Review, Vol. 11, No. 2 (Summer 2004), pp. 46-80. In 1954, Israeli intelligence forces bombed a U.S. diplomatic facility in Cairo in a bungled attempt to sow discord between Egypt and the United States. Shlaim, Iron Wall, pp. 110-113.

${ }^{60}$ Steven M. Cohen, The 2004 National Survey of American Jews, sponsored by the Jewish Agency for Israel's Department of Jewish-Zionist Education, February 24, 2005. The figure two years earlier was 28 percent. See Steven M. Cohen, The 2002 National Survey of American Jews, sponsored by the Jewish Agency for Israel's Department of Jewish-Zionist Education, conducted in November-December 2002. Also see Amiran Barkat, "Young American Jews Are More Ambivalent Toward Israel, Study Shows," Ha'aretz, March 7, 2005; Steven M. Cohen, "Poll: Attachment of U.S. Jews to Israel Falls in Past 2 Years," Forward, March 4, 2005; M.J. Rosenberg, "Letting Israel Sell Itself," Israel Policy Forum Issue Brief \#218, March 18, 2005. 
${ }^{61}$ J.J. Goldberg, “Old Friend, Shattered Dreams,” Forward, December 24, 2004; Esther Kaplan, "The Jewish Divide on Israel," Nation, July 12, 2004; Michael Massing, "Conservative Jewish Groups Have Clout," Los Angeles Times, March 10, 2002; Eric Yoffie, "Reform the Conference," Forward, August 2, 2002.

${ }^{62}$ Ori Nir, “FBI Probe: More Questions Than Answers.” Forward, May 13, 2005.

${ }^{63}$ Inigo Gilmore, "U.S. Jewish Leader Hit over Letter," London Sunday Telegraph, August 12, 2003; Isi Liebler, "When Seymour Met Condi," Jerusalem Post, November 24, 2005. Also see Sarah Bronson, “Orthodox Leader: U.S. Jews Have No Right to Criticize Israel, Ha'aretz, August 2, 2004.

${ }^{64}$ Liebler, "When Seymour Met Condi"; Ori Nir, "O.U. Chief Decries American Pressure on Israel," Forward, December 2, 2005; Idem, "Rice Trip Raises Concern over U.S. Pressure on Israel," Forward, November 18, 2005; Seymour D. Reich, "Listen to America," Jerusalem Post, November 13, 2005.

${ }^{65}$ Jeffrey H. Birnbaum, “Washington's Power 25," Fortune, December 8, 1997. AIPAC was ranked number 4 in a similar study conducted in 2001. See Jeffrey H. Birnbaum and Russell Newell, “Fat and Happy in D.C.," Fortune, May 28, 2001.

${ }^{66}$ Richard E. Cohen and Peter Bell, "Congressional Insiders Poll," National Journal. March 5, 2005; James D. Besser, "Most Muscle? It's NRA, Then AIPAC and AARP," Chicago Jewish Star, March 11-24, 2005.

${ }^{67}$ See Max Blumenthal, "Born-Agains for Sharon," salon.com, October 30, 2004; Darrell L. Bock, "Some Christians See a 'Road Map' to End Times," Los Angeles Times, June 18, 2003; Nathan Guttman, "Wiping Out Terror, Brining On Redemption,” Ha'aretz, April 29, 2002; Tom Hamburger and Jim VandeHei, "Chosen People: How Israel Became a Favorite Cause of Christian Right," Wall Street Journal, May 23, 2002; Paul Nussbaum, "Israel Finds an Ally in American Evangelicals," Philadelphia Inquirer, November 17, 2005. Daniel Pipes maintains that, "other than the Israel Defense Forces, America's Christian Zionists may be the Jewish state's ultimate strategic asset." "[Christian Zionism:] Israel's Best Weapon?" New York Post, July 15, 2003.

${ }^{68}$ The weakness of the "Palestinian Lobby" in the United States is captured in the headlines of these two articles: Nora Boustany, "Palestinians' Lone Hand in Washington," Washington Post, April, 19, 2002; George Gedda, "PLO Loses D.C. Office Because of Unpaid Rent," Chicago Tribune, April 12, 2002. On the weak impact of the "Arab Lobby," see Ali A. Mazrui, "Between the Crescent and the Star-Spangled Banner: American Muslims and U.S. Foreign Policy," International Affairs, Vol. 72, No. 3 (July 1996), pp. 493-506; Nabeel A. Khoury, “The Arab Lobby: Problems and Prospects," 
Middle East Journal, Vol. 41, No. 3 (Summer 1987), pp. 379-396; Andrea Barron, "Jewish and Arab Diasporas in the United States and Their Impact on U.S. Middle East Policy," in Yehuda Lukacs and Abdalla M. Battah, eds., The Arab-Israeli Conflict: Two Decades of Change (London: Westview, 1988), pp. 238-259.

${ }^{69}$ Jake Tapper, “Questions for Dick Armey: Retiring, Not Shy,” New York Times Magazine, September 1, 2002. Also, Tom DeLay has called himself "an Israeli at heart." See James Bennet, "DeLay Says Palestinians Bear Burden for Achieving Peace," New York Times, July 30, 2003.

${ }^{70}$ Quoted in Mitchell Bard, "Israeli Lobby Power," Midstream, Vol. 33, No. 1 (January 1987), pp. 6-8.

${ }^{71}$ Quoted in Edward Tivnan, The Lobby: Jewish Political Power and American Foreign Policy (NY: Simon and Schuster, 1987), p. 191. J.J. Goldberg, the editor of the Forward, said in 2002, “There is this image in Congress that you don't cross these people or they take you down." Quoted in John Diamond and Brianna B. Piec, "Pro-Israel Groups Intensify Political Front in U.S.," Chicago Tribune, April 16, 2002.

${ }^{72}$ Quoted in Camille Mansour, Beyond Alliance: Israel in U.S. Foreign Policy, trans. James A. Cohen (NY: Columbia University Press, 1994), p. 242.

${ }^{73}$ Although AIPAC has been able to use its political muscle to avoid having to register as a foreign agent for another government, it is especially concerned about that problem today because of the Larry Franklin spy scandal, and thus it is going to considerable lengths to emphasize its "American side." See Ori Nir, "Leaders Fear Probe Will Force Pro-Israel Lobby to File as 'Foreign Agent' Could Fuel Dual Loyalty Talk," Forward, December 31, 2004; Idem, "Leaders Stress American Side of AIPAC," Forward, May 27, 2005.

74 "Sen. Hollings Floor Statement Setting the Record Straight on His Mideast Newspaper Column," May 20, 2004, a copy of which can be found on the former Senator's web site.

75 Published in an AIPAC advertisement in the Chicago Jewish Star, August 29 September 11, 2003. Sharon is not alone in his appraisal of AIPAC's power. Senate Minority Leader Harry Reid says that "I can't think of a policy organization in the country as well-organized or respected [as AIPAC]" and former House Speaker Newt Gingrich called it "the most effective general interest group . . across the entire planet." Former President Bill Clinton described AIPAC as "stunningly effective" and "better than anyone else lobbying in this town." Quotations downloaded from the AIPAC website on January 14, 2005 [www.aipac.org/documents/whoweare.html\#say]. 
${ }^{76}$ Thomas B. Edsall and Alan Cooperman, "GOP Uses Remarks to Court Jews," Washington Post, March 13, 2003. Also see James D. Besser, "Jews' Primary Role Expanding," Jewish Week, January 23, 2004; Alexander Bolton, "Jewish Defections Irk Democrats," The Hill, March 30, 2004; E.J. Kessler, "Ancient Woes Resurfacing as Dean Eyes Top Dem Post," Forward, January 28, 2005. Hamilton Jordan wrote a memorandum to President Jimmy Carter in June 1977, in which he said: "Out of 125 members of the Democratic National Finance Council, over 70 are Jewish; In 1976, over $60 \%$ of the large donors to the Democratic Party were Jewish; Over $60 \%$ of the monies raised by Nixon in 1972 was from Jewish contributors; Over 75\% of the monies raised in Humphrey's 1968 campaign was from Jewish contributors; Over $90 \%$ of the monies raised by Scoop Jackson in the Democratic primaries was from Jewish contributors; In spite of the fact that you were a long shot and came from an area of the country where there is a smaller Jewish community, approximately $35 \%$ of our primary funds were from Jewish supporters. Wherever there is major political fundraising in this country, you will find American Jews playing a significant role." Hamilton Jordan, Confidential File, Box 34, File “Foreign Policy/Domestic Politics Memo, HJ Memo, 6/77," declassified June 12, 1990.

77 Douglas Brinkley, “Out of the Loop," The New York Times, December 29, 2002. Lawrence Kaplan reports that after Bruce Riedel, the Middle East expert on the National Security Council, left his job at the end of 2001, the Pentagon "held up the appointment of Riedel's designated successor, Middle East expert Alina Romanowski, whom Pentagon officials suspect of being insufficiently supportive of the Jewish state." “Torpedo Boat: How Bush Turned on Arafat," New Republic, February 18, 2003. The position was eventually filled by Elliot Abrams, a fervent supporter of Israel. "Indeed, for the government of Israel," Nathan Guttman wrote, "it is a gift from heaven." See "From Clemency to a Senior Post," Ha'aretz, December 16, 2002.

${ }^{78}$ E.J. Kessler, "Lieberman and Dean Spar Over Israel," Forward, September 9, 2003; Stephen Zunes, "Attacks on Dean Expose Democrats' Shift to the Right," Tikkun, November/December 2003.

${ }^{79}$ Zunes, "Attacks on Dean"; James D. Besser, “Dean's Jewish Problem," Chicago Jewish Star, December 19, 2003 -- January 8, 2004.

${ }^{80}$ E.J. Kessler, "Dean Plans to Visit Israel, Political Baggage in Tow," Forward, July 8, 2005; Zunes, "Attacks on Dean."

${ }^{81}$ Laura Blumenfeld, "Three Peace Suits; For These Passionate American Diplomats, a Middle East Settlement is the Goal of a Lifetime," Washington Post, February 24, 1997. 
82 Samuel ("Sandy") Berger, President Clinton's National Security Advisor, reports that at one point during the negotiations at Camp David (July 2000), Dennis Ross made the remarkable comment that, "If Barak offers anything more, I'll be against this agreement." Unedited transcript of "Comments by Sandy Berger at the Launch of How Israelis and Palestinians Negotiate (USIP Press, 2005)," U.S. Institute of Peace, Washington, DC, June 7, 2005.

${ }^{83}$ Quoted in Blumenfeld, "Three Peace Suits."

${ }^{84}$ Eric Alterman, “Intractable Foes, Warring Narratives," MSNBC.com, March 28, 2002.

${ }^{85}$ Quoted in Bret Stephens, "Eye on the Media by Bret Stephens: Bartley's Journal," Jerusalem Post, November 21, 2002.

${ }^{86}$ Max Frankel, The Times of My Life And My Life with the Times (NY: Random House, 1999), pp. 401-403.

${ }^{87}$ Felicity Barringer, "Some U.S. Backers of Israel Boycott Dailies Over Mideast Coverage That They Deplore," New York Times, May 23, 2002.

${ }^{88}$ Barringer, "Some U.S. Backers"; Gaby Wenig, "NPR Israel Coverage Sparks Protests," The Jewish Journal of Greater Los Angeles, May 9, 2003; Gila Wertheimer, "NPR Dismisses Protest Rallies," Chicago Jewish Star, May 30 - June 12, 2003. Also see James D. Besser, "NPR Radio Wars Putting Jewish Groups in a Bind," Jewish Week, May 20, 2005; Samuel Freedman, "From 'Balance' to Censorship: Bush's Cynical Plan for NPR," Forward, May 27, 2005; Nathan Guttman, "Enough Already from Those Pro-Israel Nudniks," Ha'aretz, February 1, 2005; E.J. Kessler, "Hot Seat Expected for New Chair of Corporation for Public Broadcasting," Forward, October 28, 2005.

${ }^{89}$ Joel Beinin, "Money, Media and Policy Consensus: The Washington Institute for Near East Policy," Middle East Report, January-February 1993, pp. 10-15; Mark H. Milstein, "Washington Institute for Near East Policy: An AIPAC 'Image Problem'," Washington Report on Middle East Affairs, July 1991.

${ }^{90}$ Quoted in Milstein, “Washington Institute.”

91 "Brookings Announces New Saban Center for Middle East Policy," Brookings Institution Press Release, May 9, 2002; Andrew Ross Sorkin, "Schlepping to Moguldom," New York Times, September 5, 2004.

92 James D. Besser, "Turning up Heat in Campus Wars," Jewish Week, July 25, 2003;

Ronald S. Lauder and Jay Schottenstein, "Back to School for Israel Advocacy," Forward, 
November 14, 2003; Rachel Pomerance, "Israel Forces Winning Campus Battle, Say Students Attending AIPAC Meeting," JTA, December 31, 2002. Jewish groups are also targeting high schools. See Max Gross, "Israel Advocacy Coalition Targeting High Schools," Forward, January 23, 2004; “New Pro-Israel Campaign Targets High School Students," JTA, June 2, 2004.

${ }^{93}$ Besser, "Turning up Heat." In 2002 and 2003, AIPAC brought 240 college students to Washington, DC for intensive advocacy training, sending them back to school to win over campus leaders to Israel's cause. Besser, “Turning up Heat"; Pomerance, "Israel Forces Winning." In the spring of 2005, it hosted 100 student government presidents (80 of whom were not Jewish) at its annual conference. Nathaniel Popper, "Pro-Israel Groups: Campuses Improving," Forward, June 24, 2005.

${ }^{94}$ Michael Dobbs, "Middle East Studies under Scrutiny in U.S.," Washington Post, January 13, 2004; Michele Goldberg, “Osama University?” Salon.com, November 6, 2003; Kristine McNeil, "The War on Academic Freedom," Nation, November 11, 2002; Zachary Lockman, "Behind the Battle over US Middle East Policy," Middle East Report Online, January 2004.

${ }^{95}$ Jonathan R. Cole, “The Patriot Act on Campus: Defending the University Post--9/11," Boston Review, Summer 2003.

${ }^{96}$ Chanakya Sethi, "Khalidi Candidacy for New Chair Draws Fire," Daily Princetonian, April 22, 2005; Idem, “Debate Grows over Khalidi Candidacy,” Daily Princetonian, April $28,2005$.

${ }^{97}$ Robert Gaines, “The Battle at Columbia University," Washington Report on Middle East Affairs, April 2005, pp. 56-57; Caroline Glick, “Our World: The Columbia Disaster," Jerusalem Post, April 4, 2005; Joseph Massad, "Witch Hunt at Columbia: Targeting the University," CounterPunch, June 3, 2005; Nathaniel Popper, "Columbia Students Say Firestorm Blurs Campus Reality," Forward, February 11, 2005; Scott Sherman, "The Mideast Comes to Columbia," Nation, April 4, 2005; Chanan Weissman, "Columbia Unbecoming," Jerusalem Post, February 6, 2005.

98 "Columbia University Ad Hoc Grievance Committee, Final Report, New York, 28 March 2005 (excerpts)," in Journal of Palestine Studies, Vol. 34, No. 4 (Summer 2005), pp. 90-100.

${ }^{99}$ Goldberg, “Osama University?"; Ron Kampeas, "Campus Oversight Passes Senate as Review Effort Scores a Victory," JTA, November 22, 2005; Stanley Kurtz, "Reforming the Campus: Congress Targets Title VI," National Review Online, October 14, 2003; McNeil, "War on Academic Freedom"; Ori Nir, "Groups Back Bill to Monitor Universities," 
Forward, March 12, 2004; Sara Roy, "Short Cuts," London Review of Books, April 1, 2004; Anders Strindberg, "The New Commissars," American Conservative, February 2, 2004.

100 The number 130 comes from Mitchell G. Bard, "Tenured or Tenuous: Defining the Role of Faculty in Supporting Israel on Campus," Report published by The Israel on Campus Coalition and The American-Israeli Cooperative Enterprise, May 2004, p. 11. Also see Nacha Cattan, "NYU Center: New Addition to Growing Academic Field," Forward, May 2, 2003; Samuel G. Freedman, "Separating the Political Myths from the Facts in Israel Studies," New York Times, February 16, 2005; Jennifer Jacobson, "The Politics of Israel Studies," Chronicle of Higher Education, June 24, 2005, pp. 10-12; Michael C. Kotzin, "The Jewish Community and the Ivory Tower: An Urgent Need for Israel Studies," Forward, January 30, 2004; Nathaniel Popper, "Israel Studies Gain on Campus as Disputes Grow," Forward, March 25, 2005.

${ }^{101}$ Quoted in Cattan, "NYU Center."

102 Jonathan Kessler, "Pro-Israel Activism Makes Comeback on Campus," Forward, December 26, 2003; Popper, "Campuses Improving”; Barry Silverman and Randall Kaplan, "Pro-Israel College Activists Quietly Successful on Campus," JTA, May 9, 2005; Chanan Tigay, "As Students Return to Campus, Activists Prepare a New Approach," JTA, September 1, 2005. Nevertheless, there are limits to the Lobby's effectiveness on campuses. See Joe Eskenazi, "Book: College Campuses Quiet, but Anti-Israel Feeling Is Growing," JTA, November 29, 2005; Gary Rosenblatt, “U.S. Grad Students Seen Hostile to Israel," Jewish Week, June 17, 2005.

${ }^{103}$ Quoted in Tony Judt, “Goodbye to All That?” Nation, January 3, 2005.

${ }^{104}$ Anti-Defamation League (ADL), “Attitudes toward Jews, Israel and the PalestinianIsraeli Conflict in Ten European Countries," April 2004; The Pew Global Attitudes Project, A Year After Iraq War: Mistrust of America in Europe Even Higher, Muslim Anger Persists (Washington, DC: The Pew Research Center for the People and the Press, March 16, 2004), pp. 4-5, 26. On the ADL survey, see "ADL Survey Finds Some Decrease in Anti-Semitic Attitudes in Ten European Countries," ADL Press Release, April 26, 2004; Shlomo Shamir, "Poll Shows Decrease in Anti-Semitic Views in Europe," Ha'aretz, April 27,2004 . These findings had virtually no effect on pro-Israel pundits, who continued to argue that anti-Semitism was rampant in Europe. See, for example, Daniel J. Goldhagen, "Europe's Toothless Reply to Anti-Semitism: Conference Fails to Build Tools to Fight a Rising Sickness" Los Angeles Times, April 30, 2004; Charles Krauthammer, "The Real Mideast 'Poison'," Washington Post, April 30, 2004.

${ }^{105}$ Martin Peretz, the editor-in-chief of the New Republic, says, "The headquarters of antiSemitic Europe today, just as during the Third Republic, is Paris." "Cambridge Diarist: 
Regrets," New Republic, April 22, 2002, p. 50. The data in this paragraph are from "AntiSemitism in Europe: Is It Really Rising?" Economist, May 4, 2002.

${ }^{106}$ Quoted in Marc Perelman, "Community Head: France No More Antisemitic Than U.S.," Forward, August 1, 2003. Also see Francois Bujon de l'Estang, "A Slander on France," Washington Post, June 22, 2002; "French President Accuses Israel of Conducting Anti-French Campaign," Ha'aretz, May 12, 2002.

107 "French Police: Anti-Semitism in France Sharply Decreased in 2005," Ha'aretz, January $19,2006$.

108 "French Protest for Murdered Jew," BBC News Online, February 26, 2006; Michel Zlotowski, “Large Memorial Held for Parisian Jew," Jerusalem Post, February 23, 2006.

${ }^{109}$ Avi Beker, “The Eternally Open Gate," Ha'aretz, January 11, 2005; Josef Joffe, “A Boom, if Not A Renaissance, in Modern-Day Germany," Forward, July 25, 2003; Nathaniel Popper, "Immigrant Policy Eyed as German Community Swells," Forward, July 25, 2003; Eliahu Salpeter, "Jews from the CIS Prefer Germany to the Jewish State," Ha'aretz, May 28, 2005. Also, the Times of London reported in the spring of 2005, that, "An estimated 100,000 Jews have returned to Russia in the past few years, sparking a dramatic renaissance of Jewish life in a country with a long history of anti-Semitism." Jeremy Page, "Once Desperate to Leave, Now Jews Are Returning to Russia, Land of Opportunity," Times, April 28, 2005. Also see Lev Krichevsky, “Poll: Russians Don't Dislike Jews, and More Are against Anti-Semitism," JTA, February 2, 2006.

110 The chairman of the Education Department of the Jewish Agency recently said that "present day violent anti-Semitism originates from two separate sources: radical Islamists in the Middle East and Western Europe as well as the neo-Nazi youth element in Eastern Europe and Latin America." Jonathan Schneider, "Anti-Semitism Still a World Problem," Jerusalem Post, January 26, 2006.

${ }^{111}$ In the ADL's April 2004 survey, "Attitudes toward Jews, Israel and the PalestinianIsraeli Conflict in Ten European Countries," the following question was asked: "In your opinion, is it very important, somewhat important, somewhat unimportant or not important at all for our government to take a role in combating anti-Semitism in our country?" The percentages for those who strongly agree or somewhat agree were Italy (92), Britain (83), Netherlands (83), France (82), Germany (81), Belgium (81), Denmark (79), Austria (76), Switzerland (74), Spain (73). See p. 19.

112 Phyllis Chesler, The New Anti-Semitism: The Current Crisis and What We Must Do about It (San Francisco: Jossey-Bass, 2003); Hillel Halkin, “The Return of Anti-Semitism: To Be against Israel Is to Be against the Jews," Wall Street Journal, February 5, 2002; Barry 
Kosmin and Paul Iganski, "Judeophobia - Not Your Parent's Anti-Semitism," Ha'aretz, June 3, 2003; Amnon Rubinstein, "Fighting the New Anti-Semitism," Ha'aretz, December 2, 2003; Gabriel Schoenfeld, The Return of Anti-Semitism (San Francisco: Encounter Books, 2003); Natan Sharansky, "Anti-Semitism is our Problem," Ha'aretz, August 10, 2003; Yair Sheleg. "A World Cleansed of the Jewish State," Ha'aretz. April 18, 2002; Yair Sheleg, "Enemies, a Post-National Story," Ha'aretz, March 8, 2003. For criticism of this perspective, see Akiva Eldar, "Anti-Semitism Can Be Self-Serving," Ha'aretz, May 3, 2002; Brian Klug, "The Myth of the New Anti-Semitism," Nation, February 2, 2004; Ralph Nader, "Criticizing Israel is Not Anti-Semitism," CounterPunch, October 16/17, 2004; Henri Picciotto and Mitchell Plitnick, eds., Reframing Anti-Semitism: Alternative Jewish Perspectives (Oakland, CA: Jewish Voice for Peace, 2004); and especially Finkelstein, Beyond Chutzpah, chapters 1-3.

${ }^{113}$ Helen Nugent, “Chief Rabbi Flays Church over Vote on Israel Assets,” Times Online, February 17, 2006. Also see Bill Bowder, "Sacks Seeks Talks after Synod Vote on Disinvestment," Church Times, February 24, 2006; "Bulldozer Motion 'Based on Ignorance'," in ibid; Ruth Gledhill, "Church Urged to Reconsider Investments with Israel," Times Online, May 28, 2005; Irene Lancaster, "Anglicans Have Betrayed the Jews," Downloaded from Moriel Ministries (UK) website, February 20, 2006; “U.K. Chief Rabbi Attacks Anglicans over Israel Divestment Vote," Ha'aretz, February 17, 2006.

114 That the Church of England was merely criticizing Israeli policy and not engaging in anti-Semitism is clearly reflected in the February 10, 2006 letter that the Archbishop of Canterbury (Dr. Rowan Williams) sent to England's Chief Rabbi (Jonathan Sacks) explaining the Church's decision on divestment. For a copy of the letter, see “Archbishop: Synod Call Was Expression of Concern," February 10, 2006, Downloaded from Church of England website, February 20, 2006.

115 Steven Kull (Principal Investigator), Americans on the Middle East Road Map (Program on International Policy Attitudes, University of Maryland, May 30, 2003), pp. 9-11, 18-19. Also see Steven Kull et al., Americans on the Israeli-Palestinian Conflict (Program on International Policy Attitudes, University of Maryland, May 6, 2002). A 2005 AntiDefamation League public opinion survey found that 78 percent of Americans believe that their government should favor neither Israel nor the Palestinians. "American Attitudes toward Israel and the Middle East," Survey conducted on March 18-25, 2005, and June 19-23, 2005, by the Marttila Communications Group for the Anti-Defamation League.

${ }^{116}$ Robert G. Kaiser, "Bush and Sharon Nearly Identical on Mideast Policy,” Washington Post, February 9, 2003. 
${ }^{117}$ Lee Hockstader and Daniel Williams, "Israel Says It Won't 'Pay Price' of Coalition," Washington Post, September 18, 2001; Jonathan Karp, "Sharon Cancels Peace Talks in Rebuff to U.S. Concerns," Wall Street Journal, September 24, 2001; Thomas Oliphant, "A Delicate Balance," Boston Globe, September 18, 2001: "Israel's Opportunity," Los Angeles Times editorial, September 18, 2001.

${ }_{118}$ Kurt Eichenwald, “U.S. Jews Split on Washington's Shift on Palestinian State," New York Times, October 5, 2001. At the same time, Prime Minister Tony Blair made "Britain's strongest endorsement yet of Palestinian statehood." Michael Dobbs, "Blair Backs Creation of Palestinian State," Washington Post, October 16, 2001.

119 James Bennet, "Sharon Invokes Munich in Warning U.S. on 'Appeasement'," New York Times, October 5, 2001; Jane Perlez and and Katharine Q. Seelye. "U.S. Stongly Rebukes Sharon for Criticism of Bush, Calling it 'Unacceptable'." New York Times October 6, 2001; Shlomo Shamir, "U.S. Jews: Sharon is 'Worried' by Terrorism Distinction," Ha'aretz, September 18, 2001; Alan Sipress and Lee Hockstader, "Sharon Speech Riles U.S.," Washington Post, October 6, 2001. For evidence that other Israelis shared Sharon's fears, see Israel Harel, "Lessons from the Next War," Ha'aretz, October 6, 2001.

${ }^{120}$ Jack Donnelly, "Nation Set to Push Sharon on Agreement," Boston Globe, October 10, 2001; Hockstader and Sipress, "Sharon Speech Riles U.S."; Perlez and Seelye. "U.S. Strongly Rebukes Sharon."

${ }^{121}$ Lee Hockstader, "Sharon Apologetic over Row with U.S.," Washington Post, October 7, 2001; Serge Schmemann, "Raising Munich, Sharon Reveals Israeli Qualms," New York Times, October 6, 2001.

${ }^{122}$ Aluf Benn, "Analysis: Clutching at Straws," Ha'aretz, September 18, 2001; "Excerpts from Talk by Sharon," New York Times, December 4, 2001; William Safire, "Israel or Arafat'," New York Times, December 3, 2001.

${ }^{123}$ Elaine Sciolino, "Senators Urge Bush Not to Hamper Israel," New York Times, November 17, 2001.

${ }^{124}$ Dana Milbank, "Bush Spokesman Gentle on Israeli Assault," Washington Post, December 3, 2001; Safire, "Israel or Arafat"; David Sanger, "U.S. Walks a Tightrope on Terrorism in Israel," New York Times, December 4, 2001.

${ }^{125}$ Keith B. Richburg and Molly Moore, "Israel Rejects Demands to Withdraw Troops," Washington Post, April 11, 2002. All quotes in this paragraph are from Fareed Zakaria, “Colin Powell's Humiliation: Bush Should Clearly Support His Secretary of State - 
Otherwise He Should Get a New One," Newsweek, April 29, 2002. Also see Mike Allen and John Lancaster, "Defiant Sharon Losing Support in White House," Washington Post, April 11, 2002, which describes the Bush Administration's anger with Sharon.

${ }^{126}$ It is worth noting that the American people were generally supportive of Bush's efforts to put pressure on Israel in the spring of 2002. A Time/CNN poll taken on April 10-11 found that 60 percent of Americans felt that U.S. aid to Israel should be cut off or reduced if Sharon refused to withdraw from the Palestinian areas he had recently occupied. "Poll: Americans Support Cutting Aid to Israel," Reuters News Release, April 12, 2002; AFP News Release, April 13, 2002. Also see Israel and the Palestinians (Program on International Policy Attitudes, University of Maryland, last updated on August 15, 2002). Moreover, 75 percent of those surveyed thought that Powell should meet with Arafat when he visited Israel. Regarding Sharon, only 35 percent found him trustworthy, while 35 percent thought he was a warmonger, 20 percent saw him as a terrorist, and 25 percent considered him an enemy of the United States.

${ }^{127}$ William Kristol and Robert Kagan, “'Senior White House Aides:' Speak Up!” Weekly Standard, April 11, 2002. For a graphic description of the heat that the Lobby put on Powell when he was in the Middle East, see Bob Woodward, Bush at War (New York: Simon and Schuster, 2002), pp. 323-326. Also see John Simpson, "Israeli Leader Has More Power in Washington than Powell," Sunday Telegraph (London), April 14, 2002, which describes a joint press conference Powell and Sharon conducted by noting that: "the Secretary of State's language, body and verbal, certainly were not that of the paymaster coming to call a client to account. Far from it. Mr. Powell seemed ingratiating, deferential; no doubt he realizes how much support Mr. Sharon has back in Washington and how much influence his friends have there with the President." It is also worth noting that former Israeli Prime Minister Benjamin Netanyahu, who was making Israel's case in the United States at the time, said even before Powell arrived in Israel that his trip "won't amount to anything." Elaine Sciolino, "Netanyahu Says Powell Mission 'Won't Amount to Anything' and Urges Arafat's Exile," New York Times, April 11, 2002.

${ }^{128}$ James D. Besser, “No Tennessee Waltz,” Jewish Week, December 27, 2002. Also see Mike Allen and Juliet Eilperin, "White House and DeLay at Odds," Washington Post April 26, 2002; Judith Eilperin and Helen Dewar, "Lawmakers Endorse Israel's Offensive," Washington Post, May 3, 2002. Bush was feeling intense pressure not just from lawmakers, but from Jewish leaders and Christian Evangelicals. See Mike Allen and John Lancaster, "Defiant Sharon Losing Support in White House," Washington Post, April 11, 2002; Dan Balz, "Bush Statement on Mideast Reflects Tension in GOP," Washington Post, April 7, 2003; Elisabeth Bumiller, "Bush Sends Aide to Speak at Rally to Quell a Growing Furor," New York Times, April 16, 2002; Bradley Burston, "Background: Can Bush Afford to Press Sharon for Peace?" Ha'aretz, May 6, 2002; Akiva Eldar, "Bush and Israel, 1991 and 2002,” Ha'aretz, May 6, 2002; Alison Mitchell, “U.S. Political Leaders 
Seek Unity on Mideast, for Now," Washington Post, April 12, 2002; William Safire, “On Being an Ally," New York Times, April 11, 2002; Alan Sipress, "Policy Divide Thwarts Powell in Mideast Effort," Washington Post, April 26, 2002; and Alan Sipress and Karen DeYoung, “U.S. Presses Ahead with Peace Efforts,” Washington Post, May 9, 2002.

${ }^{129}$ Randall Mikkelsen, "White House Calls Sharon 'Man of Peace'," Reuters, April 11, 2002; Bill Sammon, "White House Softens Tone with Israel," Washington Times, April 12, 2002.

${ }^{130}$ Peter Slevin and Mike Allen, "Bush: Sharon A 'Man of Peace'," Washington Post, April 19, 2002; David Sanger, "President Praises Effort by Powell in the Middle East," New York Times, April 19, 2002. For a transcript of the press conference, see "President Bush, Secretary Powell Discuss Middle East," White House, Office of the Press Secretary, April 18, 2002.

${ }^{131}$ Eilperin and Dewar, “Lawmakers Endorse Israel's Offensive”; Juliet Eilperin and Mike Allen, "Hill Leaders Plan Votes on Pro-Israel Relations," Washington Post, May 2, 2002; Alison Mitchell, "House and Senate Support Israel in Strong Resolutions," New York Times, May 3, 2002. For copies of the two resolutions, see "2 Resolutions 'Expressing Solidarity with Israel'," New York Times, May 3, 2002. Also see Matthew E. Berger, "Bills in Congress Boost Israel, Treat Arafat as Terrorist," Jewish Bulletin, April 26, 2002.

${ }^{132}$ Arieh O'Sullivan, “Visiting Congressmen Advise Israel to Resist Administration Pressure to Deal with Arafat," Jerusalem Post, May 6, 2002.

${ }^{133}$ Eli Lake, “Israeli Lobby Wins \$200 Million Fight," United Press International, May 11, 2002.

${ }^{134}$ Quoted in Jefferson Morley, "Who's in Charge?" Washington Post, April 26, 2002. As Akiva Eldar noted just before Sharon steamrolled Bush, "Sharon has a lot of experience sticking it to the Americans .... Ultimately, whether it was Palestinian terror, Arafat's mistakes, or domestic politics, the Americans were sent to the peanut gallery." See his “Words Are Not Enough," Ha'aretz, April 8, 2002. Nor was Bush's humiliation lost on commentators around the world. Spain's leading daily, El Pais, expressed the views of many outside observers when it commented, "If a country's weight is measured by its degree of influence on events, the superpower is not the USA but Israel." Quoted in Morley, "Who's in Charge?"

${ }^{135}$ Bradley Burston, “Hamas 'R' Us,” Ha'aretz, January 18, 2006; Akiva Eldar, “Kadima to A New Middle East," Ha'aretz, December 19, 2005; Idem, "Who Needs Abu Mazen?" Ha'aretz, November 7, 2005; Ran HaCohen, "Hamas and Israel: Rival Twins," AntiWar.com, February 6, 2006; M.J. Rosenberg, “No Partner -- As Always,” IPF Friday, 
Issue No. 260, February 3, 2006; Danny Rubenstein, "All We Did Was Switch the NonPartner," Ha'aretz, February 5, 2006; “Disarray Among the Palestinians," New York Times editorial, January 17, 2006.

${ }^{136}$ Regarding the views of previous Presidents, see Clyde R. Mark, "Israeli-United States Relations," Issue Brief for Congress (Washington, DC: Congressional Research Service, August 29, 2002), p. 7. On April 14, 2004, Bush broke with his predecessors and proclaimed that Israel would not have to return all of the territories that it occupied in 1967, and that Palestinian refugees would not be allowed to return to their former homes in Israel, but would have to settle in a new Palestinian state. See "Statement by the President Regarding Israel-Arab Peace Process," April 14, 2004; and "President Bush's Letter to Prime Minister Sharon," April 14, 2004.

137 "US Scowcroft Criticizes Bush Admin's Foreign Policy," Financial Times, October 13, 2004. Also see Glenn Kessler, "Scowcroft is Critical of Bush," Washington Post, October 16, 2004.

${ }^{138}$ On Kerry, see Gadi Dechter, “Analysis: President Kerry on Israel," United Press International press release, July 9, 2004; Nathan Guttman, "Kerry Position Paper Outlines Support for Israel," Ha'aretz, July 2, 2004: Nathan Guttman, "Kerry Jumps on Sharon Bandwagon in Favoring Gaza Disengagement Plan," Ha'aretz, April 25, 2004. On Clinton, see Adam Dickter, "Hillary: 'I Had A Lot to Prove'," Jewish Week, November 18, 2005; Kristen Lombardi, "Hillary Calls Israel a 'Beacon' of Democracy," Village Voice, December 11, 2005; Sonia Verma, "Clinton Stressed U.S.-Israel Coalition," Newsday, November 15, 2005; Rachel Zabarkes Friedman, "Senator Israel," National Review Online, May 25, 2005.

${ }^{139}$ Emad Mekay, "Iraq Was Invaded 'to Protect Israel' - US Official," Asia Times Online, March 31, 2004. Zelikow also served with Rice on the National Security Council when George H. W. Bush was President, and co-authored a book with her on German reunification. He was also one of the principal authors of the second Bush Administration's 2002 National Security Strategy, which is the most comprehensive official presentation of the so-called Bush Doctrine.

${ }^{140}$ Jason Keyser, "Israel Urges U.S. to Attack," Washington Post, August 16, 2002. Also see Aluf Benn, "PM Urging U.S. Not to Delay Strike against Iraq," Ha'aretz, August 16, 2002; Idem, "PM Aide: Delay in U.S. Attack Lets Iraq Speed Up Arms Program," Ha'aretz, August 16, 2002; Reuven Pedhatzur, "Israel's Interest in the War on Saddam," Ha'aretz, August 4, 2002; Ze'ev Schiff, “Into the Rough,” Ha'aretz, August 16, 2002.

${ }^{141}$ Gideon Alon, "Sharon to Panel: Iraq is Our Biggest Danger," Ha'aretz, August 13, 2002. At a White House press conference with President Bush on October 16, 2002, 
Sharon said: "I would like to thank you, Mr. President, for the friendship and cooperation. And as far as I remember, as we look back towards many years now, I think that we never had such relations with any President of the United States as we have with you, and we never had such cooperation in everything as we have with the current administration." For a transcript of the press conference, see "President Bush Welcomes Prime Minister Sharon to White House; Question and Answer Session with the Press," U.S. Department of State, October 16, 2002. Also see Kaiser, "Bush and Sharon Nearly Identical on Mideast Policy."

${ }^{142}$ Shlomo Brom, "An Intelligence Failure," Strategic Assessment (Jaffee Center for Strategic Studies, Tel Aviv University), Vol. 6, No. 3 (November 2003), p. 9. Also see "Intelligence Assessment: Selections from the Media, 1998-2003," in ibid., pp. 17-19; Gideon Alon, "Report Slams Assessment of Dangers Posed by Libya, Iraq," Ha'aretz, March 28, 2004; Dan Baron, "Israeli Report Blasts Intelligence for Exaggerating the Iraqi Threat," JTA, March 28, 2004; Greg Myre, "Israeli Report Faults Intelligence on Iraq," New York Times, March 28, 2004; James Risen, State of War: The Secret History of the CIA and the Bush Administration (New York: Simon \& Schuster, 2006), pp. 72-73.

${ }^{143}$ Marc Perelman, "Iraqi Move Puts Israel in Lonely U.S. Corner," Forward, September 20, 2002. This article begins, "Saddam Hussein's surprise acceptance of 'unconditional' United Nations weapons inspections put Israel on the hot seat this week, forcing it into the open as the only nation actively supporting the Bush administration's goal of Iraqi regime change." Peres became so frustrated with the UN process in the following months that in mid-February 2003 he lashed out at the French by questioning France's status as a permanent member of the Security Council. "Peres Questions France Permanent Status on Security Council," Ha'aretz, February 20, 2003. On a visit to Moscow in late September 2002, Sharon made it clear to Russian President Putin, who was leading the charge for new inspections, "that the time when these inspectors could have been effective has passed." Herb Keinon, "Sharon to Putin: Too Late for Iraq Arms Inspection," Jerusalem Post, October 1, 2002.

${ }^{144}$ Ehud Barak, “Taking Apart Iraq's Nuclear Threat," New York Times, September 4, 2002.

${ }^{145}$ Benjamin Netanyahu, "The Case for Toppling Saddam," Wall Street Journal, September 20, 2002. The Jerusalem Post was particularly hawkish on Iraq, frequently running editorials and op-eds promoting the war, and hardly ever running pieces against it. Representative editorials include "Next Stop Baghdad," Jerusalem Post, November 15, 2001; “Don't Wait for Saddam," Jerusalem Post, August 18, 2002; "Making the Case for War," Jerusalem Post, September 9, 2002. For some representative op-eds, see Ron Dermer, “The March to Baghdad," Jerusalem Post, December 21, 2001; Efraim 
Inbar, "Ousting Saddam, Instilling Stability," Jerusalem Post, October 8, 2002; Gerald M. Steinberg, "Imagining the Liberation of Iraq," Jerusalem Post, November 18, 2001.

${ }^{146}$ Aluf Benn, “Background: Enthusiastic IDF Awaits War in Iraq," Ha'aretz, February 17, 2002. Also see James Bennet, "Israel Says War on Iraq Would Benefit the Region," New York Times, February 27, 2003; Chemi Shalev, "Jerusalem Frets As U.S. Battles Iraq War Delays," Forward, March 7, 2003.

${ }^{147}$ Indeed, a February 2003 poll reported that 77.5 percent of Israeli Jews wanted the United States to attack Iraq. Ephraim Yaar and Tamar Hermann, "Peace Index: Most Israelis Support the Attack on Iraq," Ha'aretz, March 6, 2003. Regarding Kuwait, a public opinion poll released in March 2003 found that 89.6 percent of Kuwaitis favored the impending war against Iraq. James Morrison, “Kuwaitis Support War," Washington Times, March 18, 2003.

${ }^{148}$ Gideon Levy, "A Deafening Silence," Ha'aretz, October 6, 2002.

${ }^{149}$ See Dan Izenberg, "Foreign Ministry Warns Israeli War Talk Fuels US AntiSemitism," Jerusalem Post, March 10, 2003, which makes clear that "the Foreign Ministry has received reports from the US" telling Israelis to cool their jets because "the US media" is portraying Israel as "trying to goad the administration into war." There is also evidence that Israel itself was concerned about being seen as driving American policy toward Iraq. See Benn, "PM Urging U.S. Not to Delay Strike"; Perelman, "Iraq Move Puts Israel in Lonely U.S. Corner." Finally, in late September 2002, a group of political consultants known as the "Israel Project" told pro-Israel leaders in the United States "to keep quiet while the Bush administration purses a possible war with Iraq." Dana Milbank, “Group Urges Pro-Israel Leaders Silence on Iraq," Washington Post, November $27,2002$.

150 The influence of the neoconservatives and their allies is clearly reflected in the following articles: See Joel Beinin, "Pro-Israel Hawks and the Second Gulf War," Middle East Report Online, April 6, 2003; Elisabeth Bumiller and Eric Schmitt, "On the Job and at Home, Influential Hawks' 30-Year Friendship Evolves," New York Times, September 11, 2002; Kathleen and William Christison, "A Rose by Another Name: The Bush Administration's Dual Loyalties," CounterPunch, December 13, 2002; Robert Dreyfuss, "The Pentagon Muzzles the CIA," The American Prospect, December 16, 2002; Michael Elliott and James Carney, "First Stop, Iraq," Time, March 31, 2003; Seymour Hersh, "The Iraq Hawks," New Yorker, Vol. 77, issue 41 (December 24-31, 2001), pp. 58-63; Glenn Kessler, “U.S. Decision on Iraq Has Puzzling Past," Washington Post, January 12, 2003; Joshua M. Marshall, “Bomb Saddam?” Washington Monthly, June 2002; Dana Milbank, "White House Push for Iraqi Strike Is on Hold," Washington Post, August 18, 2002; Susan 
Page, "Showdown with Saddam: The Decision to Act," USA Today, September 11, 2002; Sam Tanenhaus, "Bush's Brain Trust," Vanity Fair, July 2003. Note that all these articles are from before the war started.

151 See Mortimer B. Zuckerman, "No Time for Equivocation," U.S. News E World Report, August 26/September 2, 2002; Idem, "Clear and Compelling Proof," U.S. News \& World Report, February 10, 2003; Idem, "The High Price of Waiting," U.S. News E World Report, March 10, 2003.

152 "An Unseemly Silence," Forward, May 7, 2004. Also see Gary Rosenblatt, "Hussein Asylum," Jewish Week, August 23, 2002; Idem, "The Case for War against Saddam," Jewish Week, December 13, 2002.

153 Just before the U.S. military invaded Iraq, Congressman James P. Moran (D-Va) created a stir when he said, "If it were not for the strong support of the Jewish community for this war with Iraq, we would not be doing this." Spencer S. Hsu, "Moran Said Jews Are Pushing War," Washington Post, March 11, 2003. However, Moran misspoke, because there was not widespread support for the war in the Jewish community. He should have said, "If it were not for the strong support of the neoconservatives and the leadership of the Israel Lobby for this war with Iraq, we would not be doing this."

154 Samuel G. Freedman, "Don't Blame Jews for This War," USA Today, April 2, 2003. Also see Ori Nir, "Poll Finds Jewish Political Gap," Forward, February 4, 2005.

${ }^{155}$ It is no exaggeration to say that in the wake of 9/11, the neoconservatives were not just determined, but were obsessed with removing Saddam from power. As one senior Administration figure put it in January, 2003, “I do believe certain people have grown theological about this. It's almost a religion - that it will be the end of our society if we don't take action now." Kessler, "U.S. Decision on Iraq Has Puzzling Past." Kessler also describes Colin Powell returning from White House meetings on Iraq, "rolling his eyes" and saying, "Jeez, what a fixation about Iraq." Bob Woodward reports in Plan of Attack (New York: Simon and Schuster, 2004), p. 410, that Kenneth Adelman "said he had worried to death as time went on and support seemed to wane that there would be no war." Also see ibid., pp. 164-165.

156 The first letter (January 26, 1998) was written under the auspices of the Project for the New American Century and can be found on its website. The second letter (February 19,1998 ) was written under the auspices of the Committee for Peace and Security in the Gulf and can be found on the Iraq Watch website. Also see the May 29, 1998 letter to Speaker of the House Newt Gingrich and Senate Majority Leader Trent Lott written 
under the auspices of the Project for the New American Century and found on its website. The neoconservatives, it should be emphasized, advocated invading Iraq to topple Saddam. See “The End of Containment," Weekly Standard, December 1, 1997, pp. 13-14; Zalmay M. Khalizad and Paul Wolfowitz, "Overthrow Him," in ibid., pp. 14-15; Frederick W. Kagan, “Not by Air Alone,” in ibid., pp. 15-16.

157 See Clinton's comments after he signed the "Iraq Liberation Act of 1998." Statement by the President, White House Press Office, October 31, 1998.

${ }^{158}$ One might think from the publicity and the controversy surrounding two books published in 2004-Richard Clarke's Against All Enemies: Inside America's War on Terror (New York: Free Press, 2004) and Ron Suskind, The Price of Loyalty: George W. Bush, the White House, and the Education of Paul O'Neill (New York: Simon and Schuster, 2004)that Bush and Cheney were bent on invading Iraq when they assumed office in late January 2001. However, this interpretation is wrong. They were deeply interested in toppling Saddam, just as Bill Clinton and Al Gore had been. But there is no evidence in the public record showing that Bush and Cheney were seriously contemplating war against Iraq before 9/11. In fact, Bush made it clear to Bob Woodward that he was not thinking about going to war against Saddam before 9/11. See Plan of Attack, p. 12. Also see Nicholas Lehmann, “The Iraq Factor," New Yorker, Vol. 76, issue 43 (January 22, 2001), pp. 34-48; Eric Schmitt and Steven Lee Meyers, “Bush Administration Warns Iraq on Weapons Programs," New York Times, January 23, 2001. And Cheney had defended the decision not to go to Baghdad throughout the 1990s and during the 2000 campaign. See Timothy Noah, "Dick Cheney, Dove," Slate, October 16, 2002; "Calm after Desert Storm," An Interview with Dick Cheney, Policy Review, No. 65 (Summer 1993). In short, even though the neoconservatives held important positions in the Bush Administration, they were unable to generate much enthusiasm for attacking Iraq before $9 / 11$. Thus, the New York Times reported in March 2001 that "some Republicans" were complaining that Rumsfeld and Wolfowitz "are failing to live up to their pre-election advocacy of stepping up efforts to overthrow President Hussein." At the same time, a Washington Times editorial asked, "Have Hawks Become Doves?" See Jane Perlez, "Capitol Hawks Seek Tougher Line on Iraq," New York Times, March 7, 2001; “Have Hawks Become Doves?" Washington Times, March 8, 2001.

${ }^{159}$ Woodward, Plan of Attack, pp. 25-26. Wolfowitz was so insistent on conquering Iraq that five days later Cheney had to tell him to "stop agitating for targeting Saddam." Page, "Showdown with Saddam." According to one Republican lawmaker, he "was like a parrot bringing [Iraq] up all the time. It was getting on the President's nerves." Elliot and Carney, "First Stop, Iraq." Woodward describes Wolfowitz as "like a drum that would not stop." Plan of Attack, p. 22.

${ }^{160}$ Woodward, Plan of Attack, pp. 1-44. 
${ }^{161}$ Regarding the neoconservatives' influence on Cheney, see Elliott and Carney, "First Stop, Iraq"; Page, "Showdown with Saddam"; Michael Hirsh, "Bernard Lewis Revisited," Washington Monthly, November 2004, pp.13-19; Frederick Kempe, "Lewis's 'Liberation' Doctrine for Mideast Faces New Tests," Wall Street Journal, December 13, 2005; Carla Anne Robbins and Jeanne Cummings, "How Bush Decided that Hussein Must Be Ousted from Atop Iraq," Wall Street Journal, June 14, 2002. On Cheney's critical role in the decision-making process, see Glenn Kessler and Peter Slevin, "Cheney is Fulcrum of Foreign Policy," Washington Post, October 13, 2002; Barbara Slavin and Susan Page, "Cheney Rewrites Roles in Foreign Policy," USA Today, July 29, 2002.

162 The New York Times reported shortly after 9/11 that, "Some senior administration officials, led by Paul D. Wolfowitz ... and I. Lewis Libby ... are pressing for the earliest and broadest military campaign against not only the Osama bin Laden network in Afghanistan, but also against other suspected terrorist bases in Iraq and in Lebanon's Bekka region." Patrick E. Tyler and Elaine Sciolino, "Bush Advisers Split on Scope of Retaliation," New York Times, September 20, 2001. Also see William Safire, "Phony War II," New York Times, November 28, 2002. Woodward succinctly describes Libby's influence in Plan of Attack (pp. 48-49): "Libby had three formal titles. He was chief of staff to Vice President Cheney; he was also national security adviser to the vice president; and he was finally an assistant to President Bush. It was a trifecta of positions probably never held before by a single person. Scooter was a power center unto himself .... Libby was one of only two people who were not principals to attend the National Security Council meetings with the president and the separate principals meetings chaired by Rice." Also see ibid., pp 50-51, 288-292, 300-301, 409-410; Bumiller and Schmitt, "On the Job and at Home"; Karen Kwiatkowski, "The New Pentagon Papers," Salon.com, March 10, 2004; Patrick E. Tyler and Elaine Sciolino, "Bush Advisers Split on Scope of Retaliation," New York Times, September 20, 2001. On Libby's relationship to Israel, an article in the Forward reports that "Israeli officials liked Libby. They described him as an important contact who was accessible, genuinely interested in Israel-related issues and very sympathetic to their cause." Ori Nir, "Libby Played Leading Role on Foreign Policy Decisions," Forward, November 4, 2005.

163 This letter was published in the Weekly Standard, October 1, 2001.

${ }^{164}$ Robert Kagan and William Kristol, “The Right War,” Weekly Standard, October 1, 2001; Charles Krauthammer, "Our First Move: Take Out the Taliban," Washington Post, October 1, 2001. Also see “War Aims," Wall Street Journal, September 20, 2001.

${ }^{165}$ Even before the dust had settled at the World Trade Center, pro-Israel forces were making the case that Saddam was responsible for 9/11. See Michael Barone, "War by Ultimatum," U.S. News and World Report, October 1, 2001; Bill Gertz, "Iraq Suspected of Sponsoring Terrorist Attacks," Washington Times, September 21, 2001; "Drain the Pond 
of Terror," Jerusalem Post editorial, September 25, 2001; William Safire, "The Ultimate Enemy," New York Times, September 24, 2001.

166 See James Bamford, A Pretext to War (New York: Doubleday, 2004); chaps. 13-14; Woodward, Plan of Attack, pp. 288-292, 297-306. Also see ibid., pp. 72, 163, 300-301.

167 Woodward, Plan of Attack, p. 290.

168 See Bamford, Pretext to War, pp. 287-291, 307-331; David S. Cloud, "Prewar Intelligence Inquiry Zeroes In On Pentagon," Wall Street Journal, March 11, 2004;

Seymour M. Hersh, "Selective Intelligence," New Yorker, Vol. 79, issue 11 (May 12, 2003), pp. 44-50; Kwiatkowski, "New Pentagon Papers"; Jim Lobe, "Pentagon Office Home to Neo-Con Network," Inter Press Service News Agency, August 7, 2003; Greg Miller, "Spy Unit Skirted CIA on Iraq," Los Angeles Times, March 10, 2004; Paul R. Pillar, "Intelligence, Policy, and the War in Iraq," Foreign Affairs, Vol. 85, No. 2 (March-April 2006), pp. 15-27; James Risen, "How Pair's Finding on Terror Led to Clash on Shaping Intelligence," New York Times, April 28, 2004; Eric Schmitt and Thom Shanker, "Threats and Responses: A C.I.A. Rival; Pentagon Sets Up Intelligence Unit." New York Times October 24, 2002.

169 The Office of Special Plans relied heavily on information from Ahmed Chalabi and other Iraqi exiles and it had close links with various Israeli sources. Indeed, the Guardian reports that it "forged close ties to a parallel, ad hoc intelligence operation inside Ariel Sharon's office in Israel specifically to bypass Mossad and provide the Bush administration with more alarmist reports on Saddam's Iraq than Mossad was prepared to authorize." Julian Borger, “The Spies Who Pushed for War,” Guardian, July 17, 2003.

170 See, for example, Douglas J. Feith, “The Inner Logic of Israel's Negotiations: Withdrawal Process, Not Peace Process," Middle East Quarterly, March 1996. For useful discussions of Feith's views, see Jeffrey Goldberg, "A Little Learning: What Douglas Feith Knew and When He Knew It," New Yorker, Vol. 81, issue 12 (May 9, 2005), pp. 3641; Jim Lobe, "Losing Feith, or is the Bush Team Shedding Its Sharper Edges?" The Daily Star, January 31, 2005; James J. Zogby, “A Dangerous Appointment: Profile of Douglas Feith, Undersecretary of Defense under Bush," Middle East Information Center, April 18, 2001; “Israeli Settlements: Legitimate, Democratically Mandated, Vital to Israel's Security and, Therefore, in U.S. Interest," The Center for Security Policy, Transition Brief No. 96-T 130, December 17, 1996. Note that the title of the latter piece, which was published by an organization in the Lobby, says that what is in Israel's interest is therefore in America's national interest. In "Losing Feith," Lobe writes: "In 2003, when Feith, who was standing in for Rumsfeld at an interagency 'Principals' Meeting' on the Middle East, concluded his remarks on behalf of the Pentagon, according to the Washington insider newsletter, The Nelson Report, [National Security Advisor 
Condoleezza] Rice said, 'Thanks Doug, but when we want the Israeli position we'll invite the ambassador'."

171 The "Clean Break" study was prepared for The Institute for Advanced Strategic and Political Studies in Jerusalem and published in June 1996.A copy can be found on the Institute's web site.

172 Akiva Eldar, "Perles of Wisdom for the Feithful," Ha'aretz, October 1, 2002.

173 "Rally Unites Anguished Factions under Flag of 'Stand with Israel'," Forward, April 19, 2002; “Forward 50," Forward, November 15, 2002.

${ }^{174}$ John McCaslin, "Israeli-Trained Cops," Washington Times, November 5, 2002; Bret Stephens, "Man of the Year," Jerusalem Post (Rosh Hashana Supplement), September 26, 2003; Janine Zacharia, "Invasive Treatment," in ibid. Other useful pieces on Wolfowitz include Michael Dobbs, "For Wolfowitz, A Vision May Be Realized," Washington Post, April 7, 2003; James Fallows, “The Unilateralist," Atlantic Monthly, March 2002, pp. 2629; Bill Keller, "The Sunshine Warrior," New York Times Magazine, September 22, 2002; "Paul Wolfowitz, Velociraptor," Economist, February 9-15, 2002.

175 According to Feith's former law partner, L. Marc Zell, Chalabi also promised to rebuild the pipeline that once ran from Haifa in Israel to Mosul in Iraq. See John Dizard, "How Ahmed Chalabi Conned the Neocons," Salon.com, May 4, 2004. In mid-June 2003, Benjamin Netanyahu announced that, "It won't be long before you will see Iraqi oil flowing to Haifa." Reuters, "Netanyahu Says Iraq-Israel Oil Line Not Pipe-Dream," $H a^{\prime}$ aretz, June 20, 2003. Of course, this did not happen and it is unlikely to happen in the foreseeable future.

${ }^{176}$ Matthew E. Berger, "New Chances to Build Israel-Iraq Ties," Jewish Journal, April 28, 2003. Also see Bamford, Pretext to War, p. 293; Ed Blanche, "Securing Iraqi Oil for Israel: The Plot Thickens," Lebanonwire.com, April 25, 2003. Nathan Guttman reports that "the American Jewish community and the Iraqi opposition" had for years "taken pains to conceal" the links between them. "Mutual Wariness: AIPAC and the Iraqi Opposition," Ha'aretz, April 8, 2003.

177 Nir, "FBI Probe." On the eve of the war, Bill Keller, who is now the executive editor of the New York Times, wrote: "The idea that this war is about Israel is persistent and more widely held than you think." Keller, "Is It Good for the Jews?" New York Times, March 8, 2003.

178 In an op-ed written in mid-2004, Hollings asked why the Bush Administration invaded Iraq when it was not a direct threat to the United States. "The answer," which 
he says "everyone knows," is "because we want to secure our friend Israel." Senator Ernest F. Hollings, "Bush's Failed Mideast Policy Is Creating More Terrorism," Charleston Post and Courier, May 6, 2004; "Sen. Hollings Floor Statement." Not surprisingly, Hollings was called an anti-Semite, a charge he furiously rejected. Matthew E. Berger, "Not So Gentle Rhetoric from the Gentleman from South Carolina," JTA, May 23, 2004; "Sen. Hollings Floor Statement"; "Senator Lautenberg's Floor Statement in Support of Senator Hollings," June 3, 2004, a copy of which can be found on Hollings' web site. On Moran, see note 151. A handful of other public figures like Patrick Buchanan, Maureen Dowd, Georgie Anne Geyer, Gary Hart, Chris Matthews, and General Anthony Zinni, have either said or strongly hinted that pro-Israel forces in the United States were the principle movers behind the Iraq war. See Aluf Benn, "Scapegoat for Israel," Ha'aretz, May 13, 2004; Matthew Berger, "Will Some Jews' Backing for War in Iraq Have Repercussions for All?" JTA, June 10, 2004; Patrick J. Buchanan, "Whose War?" American Conservative, March 24, 2003; Ami Eden, "Israel's Role: The 'Elephant' They're Talking About," Forward, February 28, 2003; "The Ground Shifts," Forward, May 28, 2004; Nathan Guttman, "Prominent U.S. Jews, Israel Blamed for Start of Iraq War," Ha'aretz, May 31, 2004; Lawrence F. Kaplan, "Toxic Talk on War," Washington Post, February 18, 2003; E.J. Kessler, “Gary Hart Says 'Dual Loyalty' Barb Was Not Aimed at Jews," Forward, February 21, 2003; Ori Nir and Ami Eden, "Ex-Mideast Envoy Zinni Charges Neocons Pushed Iraq War to Benefit Israel," Forward, May 28, 2004.

${ }^{179}$ Michael Kinsley, "What Bush Isn't Saying about Iraq," Slate, October 24, 2002. Also see idem, "J'Accuse."

${ }^{180}$ Robert S. Greenberger and Karby Leggett, “President’s Dream: Changing Not Just Regime but a Region: A Pro-U.S., Democratic Area is a Goal that Has Israeli and Neo Conservative Roots," Wall Street Journal, March 21, 2003. Also see George Packer, "Dreaming of Democracy," New York Times Magazine, March 2, 2003. Although not all neoconservatives are Jewish, most of the founders were and virtually all were strong supporters of Israel. According to Gal Beckerman in the Forward, "If there is an intellectual movement in America to whose invention Jews can lay sole claim, neoconservatism is it." See "The Neoconservative Persuasion," Forward, January 6, 2006.

181 See, for example, Rebuilding America's Defenses: Strategy, Forces and Resources for a New Century, A Report for the New American Century, September 2000, p. 14.

${ }_{182}$ Martin Indyk, “The Clinton Administration's Approach to the Middle East," Speech to Soref Symposium, Washington Institute for Near East Policy, May 18, 1993. Also see Anthony Lake, "Confronting Backlash States," Foreign Affairs, Vol. 73. No. 2 (March/April 1994), pp. 45-53. 
${ }^{183}$ Barbara Conry, "America's Misguided Policy of Dual Containment in the Persian Gulf," Foreign Policy Briefing No. 33, CATO Institute, November 10, 1994; Gregory F. Gause III, "The Illogic of Dual Containment," Foreign Affairs, Vol. 73. No. 2 (March/April 1994), pp. 56-66; Zbigniew Brzezinski and Brent Scowcroft, Differentiated Containment: U.S. Policy Toward Iran and Iraq, Report of an Independent Study Group on Gulf Stability and Security, Council on Foreign Relations, New York, 1997.

${ }^{184}$ Brzezinski and Scowcroft, Differentiated Containment, p. 6.

${ }^{185}$ Brzezinski and Scowcroft, Differentiated Containment, p. 130.

${ }^{186}$ For example, the Jerusalem Post noted in an editorial (September 9, 2002) that "according to Middle East expert Bernard Lewis, a post-Saddam Iraq is one that would be more likely to make peace with Israel, defang Arab radicalism, and perhaps even catalyze revolutionary forces in present-day Iran." Similarly, Michael Ledeen wrote on August 6, 2002 in the National Review Online ("Scowcroft Strikes Out") that, "If ever there was a region that richly deserved being cauldronized, it is the Middle East today. If we wage the war effectively, we will bring down the terror regimes in Iraq, Iran, and Syria, and either bring down the Saudi monarchy or force it to abandon its global assembly line to indoctrinate young terrorists." On August 19, Joshua Muravchik argued in the New York Times ("Democracy's Quiet Victory") that, "Change toward democratic regimes in Tehran and Baghdad would unleash a tsunami across the Islamic world." Also see Marina Ottaway et al., “Democratic Mirage in the Middle East," Policy Brief \#20 (Washington, D.C: Carnegie Endowment for International Peace, October 2002).

${ }^{187}$ Charles Krauthammer, "Peace through Democracy," Washington Post, June 28, 2002.

${ }^{188}$ Benn, "Background." Also, the New York Times reported that Halevy gave a speech in Munich in February 2003 in which he said, "The shock waves emerging from postSaddam Baghdad could have wide-ranging effects in Tehran, Damascus, and in Ramallah." The Times article went on to say that Israel "is hoping that once Saddam Hussein is dispensed with, the dominoes will start to tumble. According to this hope ... moderates and reformers throughout the region would be encouraged to put new pressure on their own governments, not excepting the Palestinian Authority of Yasir Arafat." Bennet, "Israel Says War on Iraq Would Benefit the Region." This same theme is reflected in a Forward article from early March 2003, which said that "Israel's top political, military and economic echelons have come to regard the looming war as a virtual deus ex machina that will turn the political and economic tables and extricate Israel from its current morass." Shalev, "Jerusalem Frets." Finally, this line of thinking was apparent in former Prime Minister Ehud Barak's previously-discussed September 4, 2002, op-ed in the New York Times. Barak maintained that "putting an end to Saddam Hussein's regime will change the geopolitical landscape of the Arab world." He claimed 
that "An Arab world without Saddam Hussein would enable many from this generation [leaders about to come into power] to embrace the gradual democratic opening that some of the Persian Gulf states and Jordan have begun to enjoy." Barak also maintained that toppling Saddam would "create an opening for forward movement on the IsraeliPalestinian conflict."

189 See Seymour M. Hersh, “The Syrian Bet,” New Yorker, Vol. 79, issue 20 (July 28, 2003), pp. 32-36; Molly Moore, "Sharon Asks U.S. to Pressure Syria on Militants," Washington Post, April 17, 2003; Ori Nir, “Jerusalem Urges Bush: Next Target Hezbollah," Forward, April 11, 2003; Idem, "Sharon Aide Makes the Case for U.S. Action against Syria, Forward, April 18, 2003; Marc Perelman, "Behind Warnings to Damascus: Reassessment of Younger Assad," Forward, April 18, 2004; Daniel Sobelman and Nathan Guttman, "PM Urges U.S. to Keep Heat on Syria, Calls Assad 'Dangerous'," Ha'aretz, April 15, 2003.

190 Moore, "Sharon Asks U.S."

${ }^{191}$ Nir, "Sharon Aide." Also see Karen DeYoung, “U.S. Toughens Warnings to Syria on Iraq, Other Issues," Washington Post, April 15, 2003.

192 Nir, "Sharon Aide." Also see Perelman, “Behind Warnings." In their efforts to demonize Syria and bait the United States into attacking it, Israelis have said that Damascus was harboring high-level Iraqis from Saddam's regime, and even worse, hiding Iraq's WMD. Perelman, "Behind Warnings"; Laurie Copans, "Israeli Military Boss Claims Iraq Had Chemical Weapons," Associated Press news release, April 26, 2004; Ira Stoll, "Saddam's WMD Moved to Syria, An Israeli Says," New York Sun, December 15, 2005; Idem, "Iraq's WMD Secreted in Syria, Sada Says," New York Sun, January 26, 2006. In August 2003, when a suicide truck bomber blew up UN headquarters in Baghdad, Israel's ambassador to the UN caused a diplomatic spat by suggesting that Syria had provided the truck, thereby implying that Syria was partly responsible. Michael Casey, "Israeli Ambassador Believes Truck Used in U.N. Bombing Came from Syria," Associated Press news release, August 21, 2003; "Israeli Envoy Links Syria to UN Blast, Stirs Flap," Reuters news release, August 21, 2003. Itmar Rabinowich, the former Israeli ambassador to the United States, told Seymour Hersh that he "wondered ... whether, given the quality of their sources, the Syrians had had advance information about the September $11^{\text {th }}$ plot -- and failed to warn the United States." Hersh, "The Syrian Bet." There was little evidence to support these charges, but Israel's willingness to make them shows how eager they were to get the United States embroiled with yet another Arab regime. 
193 Syria had been in the Lobby's gunsights well before 9/11. In fact, Syria, not Iraq, was the main target in the "Clean Break"study that Feith, Perle, and Wurmser wrote for Netanyahu in 1996. And Daniel Pipes and Ziad Abdelnour, the head of the U.S. Committee for a Free Lebanon (USCFL), had co-authored a 2000 report calling for the United States to use military threats to force Syria to remove its troops from Lebanon, get rid of any WMD it might have, and stop supporting terrorism. ("Ending Syria's Occupation of Lebanon: The U.S. Role," Report of the Middle East Study Group, Middle East Forum, May 2000.) The UCSFL is a close cousin of the Lobby, and it includes numerous neoconservatives (Abrams, Feith, Ledeen, Perle, and Wurmser) among its "official core supporters." Jordan Green, "Neocons Dream of Lebanon," ZNet, July 23, 2003; David R. Sands, "Hawks Recycle Arguments for Iraq War against Syria," Washington Times, April 16, 2003. Except for Ledeen, they all signed the 2000 report, as did pro-Israel Congressman Eliot Engel (D-NY), another core supporter of UCSFL.

${ }^{194}$ Nathan Guttman, “Some Senior U.S. Figures Say Syria Has Crossed the Red Line," Ha'aretz, Aril 14, 2004; Michael Flynn, "The War Hawks: The Right Flexes Muscle with New U.S. Agenda," Chicago Tribune, April 13, 2003. In addition to Perle and Wolfowitz, John Bolton pushed hard from inside the Administration for regime change in Syria. He had told Israeli leaders a month before the Iraq war that the Bush Administration would deal with Syria, as well as Iran and North Korea, right after Saddam fell from power. Flynn, "The Right Flexes Muscle." In pursuit of that goal, Bolton reportedly prepared to tell Congress in mid-July that Syria's WMD programs had reached the point where they were a serious threat to stability in the Middle East and had to be dealt with sooner rather than later. However, the CIA and other government agencies objected, claiming that Bolton's analysis greatly inflated the Syrian threat. Consequently, the Administration did not allow Bolton to give his testimony on Syria at that time. Douglas Jehl, “New Warning Was Put Off on Weapons Syria Plans," New York Times, July 18, 2003; Marc Perelman, "State Department Hawk under Fire in Intelligence Flap over Syria," Forward, July 25, 2003; Warren P. Strobel and Jonathan S. Landay, "Intelligence Data on Syria Now Disputed," Philadelphia Inquirer, July 17, 2003. Yet Bolton was not put off for long. He appeared before Congress in September 2003 and described Syria as a growing threat to U.S. interests in the Middle East. Nathan Guttman, "US: Syria Supporting Terror, Developing Weapons of Mass Destruction," Ha'aretz, September 16 2003.

${ }^{195}$ Quoted in Robin Wright, "U.S. Insists Syria Alter Its Course," Los Angeles Times, April 14, 2003. Also see Martin Indyk's and Dennis Ross's tough-minded rhetoric about Syria in Hersh, "The Syrian Bet."

${ }^{196}$ Lawrence F. Kaplan, “White Lie," New Republic, April 21\& 28, 2003. Also see William Kristol and Lawrence F. Kaplan, The War over Iraq: Saddam's Tyranny ad America's Mission (New York: Encounter Books, 2003). 
197 DeYoung, "U.S. Toughens Stance." There was a story in Ha'aretz ("NY Congressman Says Will Push Bill to Pressure Syria") on August 19, 2003, which reported that Engel had just met with Sharon in his Jerusalem Office for 90 minutes and the Israeli leader had endorsed Engel's efforts to push the Syria Accountability Act. Regarding the specifics of that legislation, see Zvi Bar'el, “Deciphering the Syrians, Ha'aretz, July 9, 2003; "The Return of the Syria Accountability Act," NewsMax.com, April 19, 2003; Claude Salhani, "The Syria Accountability Act: Taking the Wrong Road to Damascus," Policy Analysis, No. 512, CATO Institute, March 18, 2004. Not surprisingly, Richard Perle called on Congress to pass the Syria Accountability Act shortly after Engel re-introduced the legislation. Sands, "Hawks Recycle Arguments."

198 Ron Kampeas, “Bush, Once Reluctant on Sanctions, Prepares to Take a Tough Line with Syria," JTA, March 16, 2004.

199 Salhani, "The Syria Accountability Act," p. 5.

${ }^{200}$ Julian Borger, “Bush Vetoes Syria War Plan," Guardian, April 15, 2003; Kampeas, "Bush, Once Reluctant."

201 See Hersh, "The Syrian Bet." Other pieces discussing the advantages for the United states of cooperating with Syria include Spencer Ackerman, "Rough Trade," New Repulic, January 13, 2003; Susan Taylor Martin, "Experts Disagree on Dangers of Syria," St. Petersburg Times, November 3, 2002; Salhani, "The Syria Accountability Act"; Stephen Zunes, “Bush Has Clear Run at Syria,” Asia Times Online, March 2, 2005.

202 Two articles that appeared in the Forward after Baghdad fell describe the driving forces behind the new U.S. policy toward Syria. In a piece in mid-April, the author noted: "A sudden flurry of U.S. warnings to Syria in recent days indicates that Washington has undertaken what Israel and its supporters here have been urging for months: a comprehensive reassessment of Syrian ruler Bashar Assad." Perelman, "Behind Warnings." A few months later in mid-July, another author noted: "During the past several months, top Israeli officials have warned their American counterparts and audiences about Assad's unreliability. American officials have echoed the stance and press reports have speculated about possible American military intervention in Syria." Marc Perelman, “Syria Makes Overture over Negotiations," Forward, July 11, 2003.

${ }^{203}$ Quoted in Alan Sipress, "Israel Emphasizes Iranian Threat," Washington Post, February 7, 2002. This article, which was written as Sharon was arriving in Washington, makes clear that Tel Aviv was "redoubling its efforts to warn the Bush administration that Iran poses a greater threat than the Iraqi regime of Saddam Hussein." Also see Seymour Hersh, "The Iran Game," New Yorker, Vol. 77, issue 38 (December 3, 2001), pp. 
42-49; Peter Hirschberg, "Background/Peres Raises Iranian Threat," Ha'aretz, February 5, 2002; David Hirst, "Israel Thrusts Iran in Line of US Fire," Guardian, February 2, 2002; "Israel Once Again Sees Iran as A Cause for Concern," Ha'aretz, May 7, 2001.

${ }^{204}$ Stephen Farrell, Robert Thomson, and Danielle Haas, "Attack Iran the Day Iraq War Ends, Demands Israel," The Times (London), September 5, 2002; Stephen Farrell and Robert Thomson, "The Times Interview with Ariel Sharon," in ibid.

205 "Ambassador to U.S. Calls for 'Regime Change' in Iran, Syria," Ha'aretz, April 28, 2003. Ten days later the New York Times reported that the Washington was growing increasingly concerned about Iran's nuclear ambitions, and that there is "a lot of hammering from the Israelis for us to take this position seriously." Steven R. Weisman, “New U.S. Concerns on Iran's Pursuit of Nuclear Arms," New York Times, May 8, 2003. Shimon Peres then published an op-ed in the Wall Street Journal on June 25 entitled, "We Must Unite to Prevent an Ayatollah Nuke." His description of the Iranian threat sounded just like his earlier description of the threat from Saddam, even including a ritual reference to the lessons of appeasement in the 1930s. Iran, he emphasized, must be told in no uncertain terms that the United States and Israel will not tolerate it going nuclear.

206 In late May 2003, Inter Press Service reported that, “The neo-cons' efforts to now focus US attention on 'regime change' in Iran has become much more intense since early May and already has borne substantial fruit." Jim Lobe, “U.S. Neo-Cons Move Quickly on Iran," Inter Press Service, May 28, 2003. In early June, the Forward reported that, "Neoconservatives inside and outside the administration have been urging an active effort to promote regime change in Tehran. Reports of possible covert actions have surfaced in recent weeks." Marc Perelman, "Pentagon Team on Iran Comes under Fire," Forward, June 6, 2003. Also see idem, "White House Is Aiming to Raise Iranian Nukes at U.N. Security Council," Forward, May 9, 2003; Idem, "New Front Sets Sights on Toppling Iran Regime," Forward, May 16, 2003. Finally, the Lobby has established close relations with Reza Pahlavi, the son of the late Shah of Iran. He is even reported to have had meetings with Netanyahu and Sharon. This relationship is similar to the Lobby's relationship with Ahmed Chalabi. Specifically, pro-Israel forces promote Pahlavi, and in return, he makes clear that if he comes to power in Iran, it will have good relations with Israel. Connie Bruck, "Exiles: How Iran's Expatriates Are Gaming the Nuclear Threat," New Yorker, Vol. 82, issue 2 (March 6, 2006), pp. 48- 63; Perelman, “New Front."

207 The flyer advertising the conference, which was entitled "The Future of Iran: Mullahcracy, Democracy and the War on Terror," can be found at a number of sites on the web. Also see Green, "Neocons Dream of Lebanon"; Lobe, "U.S. Neo-Cons Move Quickly." 
${ }^{208}$ William Kristol, “The End of the Beginning," Weekly Standard, February 12, 2003. Others writing articles at the time include Daniel Pipes and Patrick Clawson, who wrote a piece on May 20 for the Jerusalem Post entitled "Turn up the Pressure on Iran." They called for the Bush Administration to support the Mujahedeen-e-Khalq, a terrorist organization based in Iraq that was bent on overthrowing the ayatollahs running Iran. Lawrence Kaplan argued in the New Republic ("Iranamok") on June 9 that the US needed to get tougher with Iran over its nuclear programs, which he feared were further along than most American policymakers recognized. Michael Ledeen, one of the leading hawks on Iran, wrote in the National Review Online ("The Others") on April 4: "There is no more time for diplomatic 'solutions.' We will have to deal with the terror masters, here and now. Iran, at least, offers us the possibility of a memorable victory, because the Iranian people openly loath the regime, and will enthusiastically combat it, if only the United States supports them in their just struggle."

${ }^{209}$ For evidence of the Lobby's intensified efforts to get the Bush Administration to deal with the Iranian nuclear problem, see Stewart Ain, "Israel Urging U.S. to Stop Iran Nukes," Jewish Week, October 7, 2005; Efraim Inbar, “The Imperatives to Use Force against Iranian Nuclearization," BESA Center [Bar-Ilan University, Israel] Perspectives, Number 12, December 1, 2005; Martin S. Indyk, "Iran's Bluster Isn't A Bluff," Los Angeles Times, November 1, 2005; Ron Kampeas, "With Time Short on Iran Nukes, AIPAC Criticizes Bush Approach," JTA, December 2, 2005; Charles Krauthammer, "In Iran, Arming for Armageddon," Washington Post, December 16, 2005; Dafna Linzer, "ProIsrael Group Criticizes White House Policy on Iran," Washington Post, December 25, 2005; Ori Nir, "New Sanction Bill Loses Momentum as Administration Presses Diplomacy," Forward, June 10, 2005; Idem, "Jewish Groups Push for Iran Sanctions," Forward, September 23, 2005; Idem, "Israeli Aides Warn U.S. Not to Drop Ball on Iran," Forward, December 9, 2005; Michael Rubin et al., "War Footing: 10 Steps America Must Take to Prevail in the War for the Free World," American Enterprise Institute, November 30, 2005; Rowan Scarborough, "Israel Pushes U.S. on Iran Nuke Solution," Washington Times, February 21, 2005.

${ }^{210}$ Some neoconservatives even welcome this outcome. For example, Robert Kagan and William Kristol wrote in the aftermath of 9/11 that, "Afghanistan will prove but an opening battle .... this war will not end in Afghanistan. It is going to spread and engulf a number of countries in conflicts of varying intensity. It could well require the use of American military power in multiple places simultaneously. It is going to resemble the clash of civilizations that everyone has hoped to avoid." "The Gathering Storm," Weekly Standard, October 29, 2002. Also see Eliot A. Cohen, "World War IV," Wall Street Journal, November 20, 2001; Phil McCombs, “The Fire This Time," Washington Post, April 13, 2003; Norman Podhoretz, "How to Win World War IV," Commentary, February 2002; Idem, "World War IV: How It Started, What It Means, and Why We Have to Win," 
Commentary, September 2004; Brian Whitaker, "Playing Skittles with Saddam," Guardian, September 3, 2002.

${ }^{211}$ Ron Kampeas, “After Restructuring, AIPAC Plans to Focus on Wider Range of Issues," JTA, September 26, 2005. 